\title{
МЕЖДУНАРОДНОЕ ЧАСТНОЕ ПРАВО РОССИИ, ФРАНЦИИ И ЕВРОПЕЙСКОГО СОЮЗА: НОВЫЕ ГОРИЗОНТЫ ДЛЯ СОВМЕСТНОГО ПРАВОСУДИЯ (обзор научно-исследовательского проекта Национального исследовательского университета «Высшая школа экономики" и Университета Париж 1 Пантеон-Сорбонна)
}

\begin{abstract}
Аннотация. В настоящем обзоре анализируются результаты научно-исследовательского проекта «Международное частное право России, Франции и Европейского Союза: новые горизонты для совместного правосудия», реализованного совместно факультетом права Национального исследовательского университета «Высшая школа экономики» и Школой права Университета Париж 1 Пантеон-Сорбонна. Цель совместного проекта состояла в достижении лучшего знания и понимания франиузской и российской правовых систем применительно кмеждународным частным отношениям. Исследования осуществлялись по трем направлениям: 1) эволючия международного частного права во Франции, в ЕС и России (проблемь федерализма и методологии в международном частном праве); 2) специфика применения иностранного права в условиях глобального финансового и экономического кризиса; 3) международньй коммерческий арбитраж и альтернативные методы разрешения международных споров в контексте мирового экономического и финансового кризиса. По первому направлению исследования работали Гетьман-Павлова И.В. (дочент кафедры международного частного права, со-руководитель проекта), Дидье Боден (Didier Boden) (доиент кафедры исследований международных частных отночений), Постникова Е.В. (стариий преподаватель кафедры международного права) и Жереми Эйманн (Је́ге́ту Неутапп) (дочент кафедры исследований международных частных отношений); по второму - Ростовцева Н.В. (доцент кафедры гражданского права), Этьен Пато (Etiennе Pataut) (профессор, со-директор кафедры исследованиймеждународных частных отношений), Чеховская С.А. (дочент кафедры предпринимательского права) и Давид Шилштейн (David Chilstein) (профессор кафедры исследований международных частных отномений); по третьему - Ерпылева Н.Ю. (профессор, заведующая кафедрой международного частного права, руководитель проекта), Паскаль де Варейль-Соммьер (Pascal de Vareilles-Sommières) (nрофессор кафедры исследованиймеждународных частных отношений, руководитель проекта), Прокудина Л.А. (заместитель заведуюшего кафедрой судебной власти и организачии правосудия, заместитель декана факультета права по науке) и Каролин Кляйнер (Caroline Kleiner) (профессор юридического факультета Страсбургского университета, со-руководитель проекта). В рамках реализации совместного научно-исследовательского проекта было проведено два кругльх стола - г. Москва, 17-18 июня 2013 г., и г. Париж, 25-26 октября 2013 г. на которых с докладами выступили все участники проекта (рабочие языки - русский и франиузский).

Ключевые слова: НИУ ВШЭ, Университет Сорбонна, совместный научно-исследовательский проект, международное частное право, Россия, Франция, Европейский Союз, методология, международный коммерческий арбитраж, публичный порядок

Abstract: This review includes analysis of the results of the scientific research project "International private law of Russia, France and the European Union: hew horizon for joint justice", which is implemented with the joint efforts of the Law Faculty of the National Research University-Higher School of Economics and the Université Paris 1 Panthéon-Sorbonne. The goal of the joint project was to achieve better knowledge and understanding of the French and Russian legal systems in respect
\end{abstract}


of international private law relations. The studies concerned three directions: 1) evolution of the international private law in France, in the EU and in Russia (problems of federalism and methodology in the international private law); 2) specific features of application of international law in the conditions of global financial and economic crisis; 3) international commercial arbitration and alternative international dispute resolutions methods within the framework of global economic and financial crisis. As for the first direction, the work was done by I.V. Getman-Pavlova (Associate Professor of the Department of International Private Law, Co-Head of the Project), Didier Boden (Associate Professor of the Department of International Private Relations Studies), E.V. Postnikova (Senior Lecturer of the Department of International Law) and Jérémy Heymann (Associate Professor of the Department of International Private Relations Studies). Within the second direction the work was done by Rostovtseva N.V. (Associate Professor of the Department of Civil Law), Etienne Pataut (Professor, Co-Director of the Department of International Private Relations Studies), S.A. Chekhovskaya (Associate Professor of the Department of Entrepreneurial Law), and David Chilstein (Professor of the Department of the International Private Relations Studies). As for the third direction, the work was done by N.Y. Erpyleva (Professor, Head of the Department of International Private Law, Head of the Project), Pascal de Vareilles-Sommières (Professor of the Department of International Private Relations Studies, Head of the Project), L.A. Prokudina (Vice-Chairperson of the Department of Judicial Power and Justice Organization, Vice-Dean of the Law Faculty on Scientific Work) and Caroline Kleiner (Professor of the Law School of the Strasbourg University, Co-Head of the Project). Within the framework of the implementation of joint scientific research project there were held two roundtables - in Moscow on June 17-18, 2013, and in Paris on October 25-26, 2013, where all of the project participants presented their theses (working languages: Russian and French).

Keywords: Scientific Research University - Higher School of Economics, Université Paris 1 Panthéon-Sorbonne, joint scientific research project, international private law, Russia, France, the European Union, methodology, international commercial arbitration, public order.

октября 2012 по октябрь 2013 гг. в рамках научного сотрудничества между Национального исследовательского университета «Высшая школа экономики» и Университетом Париж 1 Пантеон-Сорбонна был реализован совместный исследовательский проект «Международное частное право России, Франции и Европейского Союза: новые горизонты для совместного правосудия» ${ }^{1}$

Цель совместного научно-исследовательского проекта состояла в достижении лучшего знания и понимания французской и российской правовых систем применительно к международным частным отношениям. Международное частное право - это ключ, открывающий доступ к другим правовым системам, к углублению общих знаний и усилению научного сотрудничества.

\section{Общая характеристика проблематики исследования}

Глобализация человеческих и экономических взаимоотношений уже долгое время представля-

\footnotetext{
${ }^{1}$ Подробная информация о совместном научном исследовании размещена на специальном сайте проекта: http:// dipfrancorusse.hypotheses.org/
}

ет настоящий вызов международному частному праву (далее - МЧП), которое имеет своей целью регулирование международных частных отношений. Никогда в истории данная отрасль права не была объектом столь значительных преобразований. Каждое государство по-своему реагирует на эти многочисленные изменения.

Франция, чье законодательство по МЧП начиная с XIX века строилось в основном на базе судебной практики, переживает кардинальное изменение способов образования правовых норм в этой области в течение последних десятилетий. Сегодня Франция как член Европейского союза (далее-ЕС) в значительной степени передоверяет регулирование этих отношений общим актам ЕС.

Российское законодательство по МЧП имеет совсем другую историю. В СССР существовала государственная монополия внешней торговли, и в международных коммерческих контрактах участвовали только строго определенные государственные предприятия. Кроме того, в СССР отсутствовала свобода передвижения, и частные лица не могли выезжать в другие государства. По этим причинам советское право фактически никак не регулировало международные частные отношения (в различных актах содержались отдельные нормы, практически всегда деклариро- 
вавшие применение только советского права). В начале 1990-х годов Российская Федерация, таким образом, столкнулась с двойной проблемой, когда возник вопрос о законодательном регулировании международных частных отношений. Разработка нового законодательства, осуществленная в период 1996-2003 гг., происходила, с одной стороны, в новом контексте либерализации общественной жизни, с другой стороны, в рамках глобальной интенсификации международных частных отношений на уровне, никогда до этого не существовавшем.

И во Франции, и в России правила МЧП претерпели серьезные изменения в конце XX - начале XXI вв. До настоящего времени не предпринималось сравнительных исследований с тем, чтобы изучить сходства и различия, которые сближают и разделяют французское и российское МЧП. Можно даже отметить некоторое равнодушие европейского законодателя по отношению к правовым системам стран, не являющихся членами $\mathrm{EC}$, в то время как взаимоотношения между ЕС и Российской Федерацией постоянно интенсифицируются. Кроме того, такое исследование является тем более необходимым сегодня, когда экономический и финансовый кризис, который по-разному затрагивает Францию, ЕС и Россию, может привести к серьезным изменениям правовых норм и подходов. Прежде всего это касается норм МЧП, которые специально предназначены для того, чтобы государство могло разрешать или запрещать применение иностранного закона в целях защиты своей экономики.

Глобализация, так же как мировой экономический и финансовый кризис, оказала влияние на нормы, регулирующие доступ к правосудию. Интенсификация международных отношений побуждает государства заранее обеспечить гарантии доступа к правосудию для иностранных граждан и воспринимать иностранные судебные решения. Однако участники международной торговли чаще прибегают к негосударственному правосудию, предпочитая ему арбитраж и другие альтернативные способы разрешения споров. Между тем, различные правовые традиции России и Франции привели к появлению различных правил доступа к правосудию.

Все эти соображения подтверждают необходимость совместного исследования эволюции норм французского, европейского и российского МЧП в современных условиях. Задачами реализованного научно-исследовательского проекта являлись развитие юридической науки во Франции и в России, а также практическое внедрение его результатов (прежде всего, в правоприменительную практику, поскольку взаимодействие между доктриной и судебной практикой в данной области очень велико).

Сравнительное изучение эволюции французского, европейского и российского МЧП в контексте глобализации и экономического кризиса было поделено на три направления, связанные друг с другом и позволяющие более эффективно и структурированно организовать совместное исследование.

\section{Направления исследования}

1. Эволюция международного частного права во Франции, в ЕС и России (проблемы федерализма и методологии в международном частном праве)

Данное направление предполагало исследование различных методов разработки норм МЧП во Франции и России. Были проанализированы значение судебной практики в области формирования, толкования и эволюции норм французского и российского МЧП; значение унифицированных материальных и коллизионных норм, разработанных международными организациями (Гаагская конференция МЧП, Комиссия ООН по праву международной торговли (ЮНСИТРАЛ), УНИДРУА) во французском, европейском и российском МЧП, делегирование французским законодателем нормативных полномочий в данной области Европейскому Союзу.

2. Специфика применения иностранного права в условиях глобального финансового и экономического кризиса

Вторая тема, связанная с первой, была посвящена рассмотрению одного из аспектов глобализации - реакции российской и французской правовых систем на экономический и финансовый кризис. В рамках данной проблемы исследовался вопрос - какое направление принимают нормы французского, европейского и российского МЧП перед лицом экономического и финансового кризиса? Можно ли говорить о развитии «про- 
текционистских» правовых средств («защитные оговорки» - императивные нормы, механизм публичного порядка, обход закона), или, напротив, национальные правовые системы демонстрируют большую открытость для применения иностранного права?

3. «Открытость» российской и французской правовых систем международному коммерческому арбитражу и другим альтернативным способам разрешения международных споров - гарантия доступа к правосудию в контексте мирового экономического и финансового кризиса (международный коммерческий арбитраж и альтернативные методы разрешения международных споров)

Интенсификация международных хозяйственных связей привела к развитию международного коммерческого арбитража и альтернативных механизмов разрешения споров. Франция и Россия являются участницами Нью-Йоркской конвенции о признании и приведении в исполнение иностранных арбитражных решений от 10 июля 1958 г. и обладают «современным» законодательством в области международного коммерческого арбитража. В 1993 г. Российская Федерация приняла новое законодательство, основанное на Типовом законе ЮНСИТРАЛ, а Франция продолжает искать «свой собственный путь» (как это показывает Декрет от 13 января 2011г., реформирующий французское арбитражное право).

Значительная доля обращений в международный коммерческий арбитраж заставляет задаться вопросом о роли государственных судов в области международной торговли. Есть ли в международных коммерческих спорах место для государственных судов? Каким образом доступ к правосудию в случае коммерческих споров гарантирован во Франции и в России? Какими правовыми средствами обладают хозяйствующие субъекты во Франции и в России для того, чтобы прибегнуть к другим способам разрешения споров (медиация, примирение и посредничество)? Лучшее взаимное понимание подходов каждого государства могло бы способствовать наиболее эффективному предотвращению спорных ситуаций и наилучшему пониманию юридических связей между хозяйствующими субъектами.

Непосредственную реализацию проекта осуществляли преподаватели факультета права
НИУ ВШЭ и Школы права Университета Париж 1 Пантеон-Сорбонна. С российской стороны в проекте участвовали: Ерпылева Н.Ю. (профессор, заведующая кафедрой международного частного права, руководитель проекта), Гетьман-Павлова И.В. (доцент кафедры международного частного права, со-руководитель проекта), Прокудина Л.А. (заместитель заведующего кафедрой судебной власти и организации правосудия, заместитель декана факультета права по науке), Постникова Е.В. (старший преподаватель кафедры международного права), Ростовцева Н.В. (доцент кафедры гражданского права), Чеховская С.А. (доцент кафедры предпринимательского права). С французской стороны в проекте участвовали: Паскаль де Варейль-Соммьер (Pascal de Vareilles-Sommières) (профессор кафедры исследований международных частных отношений, руководитель проекта), Каролин Кляйнер (Caroline Kleiner) (профессор юридического факультета Страсбургского университета, со-руководитель проекта), Этьен Пато (Etienne Pataut) (профессор, со-директор кафедры исследований международных частных отношений), Дидье Боден (Didier Boden) (доцент кафедры исследований международных частных отношений), Жереми Эйманн (Jérémy Heymann) (доцент кафедры исследований международных частных отношений), Давид Шилштейн (David Chilstein) (профессор кафедры исследований международных частных отношений).

В рамках реализации совместного научно-исследовательского проекта было проведено два круглых стола - г. Москва, 17-18 июня 2013 г., и г. Париж, 25-26 октября 2013 г. - на которых с докладами выступили все участники проекта (рабочие языки - русский и французский²). Были также разработана совместная база данных и создан сайт для размещения (на французском, русском и английском языках) российских, французских и европейских нормативно-правовых актов, судебной и арбитражной практики по международному частному праву.

По первому направлению исследования «Проблемы федерализма и методологии в международном частном праве» с докладами выступили:

\footnotetext{
2 Перевод с русского языка на французский и с французского языка на русский - Елена Федорова и Юлия Ямова.
} 
Дидье Боден ${ }^{3}$ в своих докладах по теме «Эволюция методов международного частного права» рассказал о проблемах современной методологии французского и европейского МЧП.

В литературе по МЧП «методом» называют способ применения права, опирающийся на теорию (или общее представление) о таковом. Теории могут в большей или меньшей степени соответствовать позитивному праву в том смысле, что, например, две несовместимые между собой теории могут соотноситься: одна - с одной частью позитивного права, а другая - с другой. Каждая теория использует основополагающие концепции (парадигмы), которые она именует и организует по-своему, выстраивает во фразы, следующие в устраивающем ее порядке; так, чтобы простое употребление некоторых слов или простой факт постановки определенных вопросов в определенном порядке, свидетельствовал о принадлежности к определенной теории, которая использует определенный метод.

Во Франции в сфере МЧП последовательно применялось четыре крупных метода: теория статутов (приблизительно до 1850 г.), теория нео-статутариев (приблизительно до 1930 г.), нео-савиньянская теория двусторонних коллизионных привязок (приблизительно 1930 2000 гг.), «новый» метод (приблизительно с 2000 г.). При этом необходимо отметить, что изменения методов или теорий не происходят моментально и можно заметить длительные переходные периоды от эпохи доминирования одного метода к следующей эпохе, отмеченной господством другого метода. В течение этих переходных периодов многие методы сосуществуют. Так, в период с 1850 по 1930 гг., характеризующийся доминированием идей нео-статутариев Манчини, Лорана и Вейса, постепенно выявилось появление идей, воспринятых из теории Савиньи, вплоть до широкого принятия в 1930 гг. нео-савиньянской теории, очищенной от примесей теории нео-статутариев.

\footnotetext{
3 Этот доклад имеет предварительный характер и представляет собой «черновой вариант», не предназначенным для распространения. Все права защищены, в том числе, на территории России.
}

Для понимания функционирования первого метода (теория статутов) можно обратиться к знаменитому Постановлению от 17 июля 1833 г., вынесенному Кассационным судом Франции по делу мадам Анны Вильмино (в замужестве Эрвас) против Бонар. Решение касалось ипотеки, предоставленной в отношении имущества, находящегося на территории Франции, французским кредитором, проживающим во Франции. Ипотека была предоставлена испанке (мадам Эрвас), состоявшей в браке с испанцем, в качестве гарантии солидарно принятого ими долга. Супруги проживали совместно на территории Франции. Долг не был возвращен в срок, и кредитор воспользовался своими правами в отношении ипотеки. Должница утверждала, что сделка по предоставлению ипотеки являлась ничтожной в соответствии с Велльяновым сенатус-консультом, действовавшим в то время в Испании, и применимым, по ее мнению, к испанкам, в каком бы месте они ни находились, в качестве их личного закона.

Билатерализация ч. 3 ст. 3 ФГК («законы, касающиеся гражданского состояния и дееспособности лиц, обязывают французов даже тогда, когда они проживают в иностранных государствах») могла бы привести к следующему результату - «гражданское состояние и дееспособность лица регулируются национальным законодательством даже тогда, когда лицо проживает в другом государстве». Однако ни Гражданский суд Сены (4 июня 1829 г.), ни Королевский суд Парижа (15 марта 1831 г.) не согласились с мадам Эрвас, которая в итоге обратилась в Кассационный суд с жалобой на постановление Суда Парижа. Ответчик в кассационной инстанции (кредитор) напомнил, что, согласно многовековой судебной практике, Велльянов сенатус-консульт применялся только к замужним женщинам, проживающим на территории его действия (даже в отношении актов, совершенных в другой стране). Соответственно, в отношении оспариваемой сделки к должнице, не проживающей на территории его действия, Велльянов сенатус-консульт применяться не может, даже если он квалифицируется в качестве ее личного статута (следующего за лицом, в каком бы месте оно ни находилось). 
Кассационный суд прямо отказал в билатерализации ч. 3 ст. 3 ФГК и квалифицировал вопрос о дееспособности замужней женщины в отношении ипотеки недвижимого имущества, находящегося на территории Франции, так, как это предусмотрено ч. 2 ст. 3 ФГК («недвижимости, даже те, которыми владеют иностранцы, подчиняются французским законам»). Кассационный суд прямо подчеркнул: «Учитывая, что если статья 3 провозглашает, что законы, касающиеся гражданского состояния и дееспособности лиц, обязывают французов даже тогда, когда они проживают в иностранных государствах, то она не содержит никакой похожей или аналогичной нормы, касающейся иностранцев, проживающих во Франции; из чего следует, что оспариваемое постановление не может нарушить эту статью. Учитывая, что в соответствии с положением этой же статьи недвижимости, даже те, которыми владеют иностранцы, подчиняются французским законам; и что, принимая решение о том, что мадам Эрвас должна была исполнить обязательство, которое она приняла на себя по французским законам в отношении ипотеки недвижимого имущества, находящегося во Франции, суд верно применил французские законы, регулирующие данное обязательство». Кассационная жалоба была отклонена.

Дело Эрвас могло бы представлять больший интерес, если бы Кассационный суд от начала до конца следовал аргументам кредитора, заявляющего о необходимости признания, что мадам Эрвас, не проживая в Испании, не может ссылаться на применение к ней Велльянова Сенатусконсульта, который, согласно толкованию всех представителей теории статутов, применялся только к женщинам, проживающим на территории его действия. Однако это не имеет значения, поскольку отказ в билатерализации нормы выражен прямо и указание французского права на его применение также выражено напрямую.

Применение второго метода (теория нео-статутариев) началось приблизительно в 1850 г., когда практически одновременно появились работы Генриха Тёля (предвестника унилатерализма), Савиньи (предвестника билатерализма) и Манчини (предвестника теории нео-статутариев, которая нашла поддержку у многих влиятельных французских юристов). Еще в 2004 г. можно было встретить французских адвокатов, получивших образование приблизительно в 1950-е гг., которые, не отдавая себе в этом отчета, повторяли высказывания нео-статутариев, относящиеся примерно к 1880 г.: «Законы, касающиеся частных правоотношений, применяются к гражданам того государства, где они были приняты, тогда как законы публичного порядка применяются ко всем лицам, находящимся на территории государства, их принявшего, в том числе, к иностранцам».

Этот метод характеризуется утопией о возможности принятия международных универсальных конвенций по унификации коллизионных привязок односторонних коллизионных норм для регулирования различных правоотношений. Такие привязки определяются и отличаются друг от друга общей коллизионной привязкой для каждого вида правоотношений: гражданство для так называемых личных законов, место нахождения вещи или место совершения акта для законов, называемых территориальными и т.д. Данная утопия об унификации коллизионных привязок односторонних коллизионных норм в области различных правоотношений посредством международных договоров стала реальностью только в Латинской Америке с принятием 28 февраля 1928 г. Гаванской конвенции о международном частном праве (Кодекса Бустаманте). Кодекс Бустаманте объединяет 15 государств и для каждого из этих государств является абсолютно непонятным. Сегодняшние юристы получили свое образование в рамках нео-савиньянского билатерализма, а понимание унифицированных односторонних коллизионных норм (например, по образцу Брюссельской конвенции по вопросам юрисдикции и принудительного исполнения судебных решений в отношении гражданских и коммерческих споров (1968)) требует такого способа применения, который современным юристам неизвестен, во всяком случае, если речь идет об определении компетентного материального права.

Во Франции, в отсутствие договора по типу Кодекса Бустаманте, юристы поступают, как если бы нормы, которые они применяют, уже являются универсальными (такой подход требует отказа от множественности систем МЧП и, таким образом, запрета отсылки). Французские юристы также считают, что законы публичного порядка 
представляют собой один из видов законов (если говорить только об одной из характерных черт данной теории).

Третий метод (нео-савиньянский билатерализм) появляется между 1928 г. (выход первого издания краткого курса Поля Леребур-Пижоньера) и 1939 г. (издание курса лекций Ганса Левальда в Гаагской Академии). Данный период отмечен волной новых работ, вышедших из-под пера различных авторов (Левальд, Мельхиор). Эти новые работы адресованные практикующим юристам, сосредоточены на праве одного государства и пропускают важные исторические и теоретические факторы. Работы авторов новой волны характеризуются желанием дать практикующим юристам простой метод, руководство по применению МЧП, алгоритм, требующий поэтапной постановки в незыблемом порядке заранее ясно определенных вопросов без того, чтобы впредь задаваться вопросом о последовательном логическом рассуждении. Это то, что Вернер Гольдшмидт назвал нормологическим методом (по аналогии с тем же методом в уголовном праве), а Францискакис - алгоритмическим методом.

Парадигмальным элементом новой волны выступает двусторонняя коллизионная норма, указывающая на применимое частное материальное право. Из области изучения исключаются международное уголовное право и родственные с ним дисциплины. Вопросы международной юрисдикции судов и силы иностранных судебных решений отодвинуты на второе место и часто решаются по аналогии (например, вопрос о применении оговорки о публичном порядке на стадии экзекватуры представлен посредством простой отсылки к тому, что уже было сказано о публичном порядке относительно применения иностранного права). Авторы новых текстов, будучи менее обеспокоенными последовательностью логических рассуждений, нежели их предшественники, добавляют к двусторонней коллизионной норме оговорку о публичном порядке и отсылку, которые в течение 50 лет до этого были двумя пугающими элементами международного частного права.

Подобное сосуществование различных методов МЧП в течение переходных периодов наблюдается и на сегодняшний день, в то время как мы, по мнению некоторых авторов, переживаем четвертую теоретическую революиию за два века существования нашей дисциплины. Можно отметить некоторые характерные черты совершающейся революции.

1. Изменения в определении объекта изучения.

Среди всех возможных юридических последствий, признаваемых за внешней нормой, применение иностранных законов привлекает повышенное внимание в 1928-1999 гг.; на сегодняшний день большее внимание привлекает изучение других последствий: принятие во внимание норм международного права, признание и исполнение судебных решений и т.д.

В течение 70 лет казалось нелепым различать два способа применения МЧП (с точки зрения правопорядка, создавшего применимую норму, - требуемое или господствующее применение, - и с точки зрения правопорядка, призванного применить такую норму - применение принятое). Сегодня такое различие является все более и более распространенным.

С 1928 по 1999 гг. МЧП сосредотачивалось (иногда в карикатурной форме) на единственном вопросе определения частного права, применимого к существу правоотношения. На сегодняшний день внимание, главным образом, сосредоточено на вопросах международной компетенции, признания и исполнения иностранных решений.

Ранее считалось, что только частное право затронуто правилами МЧП, а сегодня и другие отрасли права начали систематически рассматриваться под этим углом (что является показателем возврата к периоду 1850-1928 гг.). Ранее в предмет МЧП включались только правовые последствия, признанные одним государством за нормами права другого государства, а в настоящий момент предлагается трансформировать МЧП в «право отношений между правопорядками» (государственными или негосударственными).

\section{2. Изменения перспектив.}

Ранее МЧП представлялось выразителем точки зрения государства (точнее, государственного суда). Сейчас развивается другая точка зрения, которая принимает во внимание индивида, находящегося в центре «перекрестного огня» противоречивых воль государств (и других правопорядков).

Уникальность правопорядка страны суда, распределяющего законодательные компетенции 
государств остального мира, уступает свое место «точки отсчета» любого рассуждения о множественности правопорядков, не согласованных между собой.

\section{3. Изменения в позитивном праве.}

Ранее основным источником французского МЧП была судебная практика, основанная, иногда искусственно, на нескольких отдельных нормах Кодекса Наполеона. Современное МЧП, действующее в большинстве стран Европы, кодифицировано, хотя Франция по-прежнему не имеет своего собственного кодекса МЧП.

Преобладание национальных норм МЧП в значительной степени уступило место преобладанию европейских унифицированных норм международного частного права государств-членов. В той мере, в которой еще существует национальное МЧП, оно испытывает все большее влияние материального права ЕС.

Вопросы признания юридической силы за внесудебными иностранными документами принимает все большее значение (документ об образовании компании, свидетельство о рождении и т.д.). Ранее юридический выбор (shopping juridique) - выбор суда, выбор lex societatis, права, применимого к вопросам наследования и т.д. - считался обходом закона. В настоящее время он считается вполне законным в контексте признания конкуренции государственных правовых систем.

В противоположность подчинению любого правового вопроса единственному закону, подлежащему применению согласно двусторонней коллизионной привязке, «диптих» Жана Паоло Романо показывает, что реальность позитивного права (по крайней мере, в отношении некоторых вопросов) свидетельствует о множественном указании на самоприменение (каждое государство признает применимым его собственное право в соответствии со многими альтернативными коллизионными привязками). Такое самоприменение компенсируется расширенным признанием (каждое государство с легкостью признает судебные решения других государств, отказывая в контроле применимого права и значительно уменьшая контроль за косвенной компетенцией).

Отношения между правопорядками (государственными или негосударственными) увеличились в особенности с того момента, как Всемирная торговая организация и Международный центр по урегулированию инвестиционных споров заняли первоочередное место в разрешении коммерческих споров. Это ведет к отказу от применения двусторонних коллизионных привязок.

4. Эпистемологические изменения.

С 1928 по 1999 гг. господство единственного метода способствовало распространению идеи, что позитивному праву соответствует лишь одна теория, и нет необходимости различать позитивное право и теорию права. В настоящее время все легче и легче различать позитивное право и теорию права, излагать одновременно множество теорий права и оценивать их значение в отношении позитивного права.

В университетской литературе 1928-1999 гг. доминировали две категории вопросов: одна касалась законодательной морали (какую двустороннюю коллизионную норму лучше добавить к уже существующим?), а другая - догматики (как применяются двусторонние коллизионные нормы?). Современная эпоха отмечена увеличивающимся разнообразием споров о праве (науке права, мета-науке, потребительском сравнении правовых систем частными лицами, экономическом анализе права и т.д.).

Изменились ценности в области законодательной морали. 1928-1999 гг. были отмечены переносом внутренних ценностей на внешний мир и на подавление идей, которые выходили за рамки этого «прокрустова ложа». Современная эпоха со стороны тех, кто разрабатывает нормы МЧП, характеризуется повышенным вниманием к помощи, которую государство может оказать частным лицам, обращающимся для реализации своих интересов к выбору правовой системы (shopping juridique).

После сосредоточения в 1928-1999 гг. каждого государства на самом себе (спровоцированного убежденностью в необходимости сфокусироваться на позитивном праве и обращаться исключительно к своим практикующим юристам) наблюдается возврат некоторого космополитизма, по крайней мере, на европейском уровне (аналогично тому, как было нелепым верить в возможность создания отдельных французской, бельгийской, немецкой и т.д. доктрин МЧП, имеющих своим общим источником европейское право).

Эти изменения или, по крайней мере, некоторые из них, представляются выражением 
действия нового метода, который можно назвать либо методом признания, либо унилатерализмом (методом односторонних коллизионных привязок).

Гетьман-Павлова И.В. ${ }^{4}$ в своих докладах по теме «Современная методология российского международного частного права» обратила внимание на две проблемы: возможность применения норм иностранного публичного права и развитие института автономии воли сторон.

Ранее в МЧП господствовал безусловный императив - иностранное публичное право не применяется. В доктрине МЧП считалось совершенно неприемлемым возможность применения иностранного публичного права. Во второй половине $\mathrm{XX}$ в. это положение утратило свой безусловно императивный характер. В настоящее время является нормальным применение иностранных гражданских процессуальных норм, наличие в законодательстве процессуальных коллизионных норм. Наиболее яркий пример ГПК Румынии (2010 г., должен вступить в силу в 2014 г.), который закрепляет развернутую систему процессуальных коллизионных норм. В связи с этим, в частности, возникает проблема терминологического характера - коллизионные нормы в МГП - это процессуальные коллизионные нормы. Как терминологически отграничить их от коллизионных норм МЧП? Может быть, нужен специальный термин - «материальная коллизионная норма», т.е. коллизионная норма, предписывающая применение нормы материального, а не процессуального права?

Намного меньше разработан вопрос о возможности применения в рамках коллизионного метода иностранных публично-правовых норм. Ранее недопустимость использования иностранных публичных законов на территории государства суда считалась общепринятым принципом МЧП. Однако в доктрине МЧП давно отмечается, что очень часто отсылка к иностранному закону заставляет судью если не применить, то, по крайней мере, учитывать иностранное публичное

\footnotetext{
${ }^{4}$ Идеи, данные и результаты исследования, проведенного при подготовке докладов, отражены в статье: Гетьман-Павлова И.В. Применение иностранных публично-правовых норм в международном частном праве // Журнал международного публичного и частного права. 2013. № 5. С. 8-12.
}

право. В советской доктрине в 1970-х годах говорилось о публичных нормах с частноправовым эффектом, отмечалось наличие коллизионных норм, которые содержат отсылки к таможенным, паспортным и санитарно-административным правилам иностранных государств, т.е. к нормам административно-правового характера. Из этого был сделан вывод, что коллизии законов могут возникать не только в гражданско-правовой области, но и в сфере административно-правовых отношений, более того, в государственном и даже в уголовном праве.

В настоящее время применение в результате отсылки национальной коллизионной нормы положений иностранного публичного права встречается достаточно часто. Это положение закреплено в национальных законодательствах (Закон о МЧП Азербайджана (2000), Закон о МЧП Украины (2005), Закон о МЧП Польши (2011)) и в международно-правовых документах - Модельный гражданский кодекс стран СНГ, Резолюция УНИДРУА (Висбаден, 1975), Резолюция 63-й конференции Ассоциации международного права (Варшава, 1988). Например, в ст. 13 Закона о МЧП Швейцарии (1987) установлено: «...Положение иностранного права не является неприменимым только по той причине, что характеризуется как положение публичного права». По существу, решение швейцарского законодателя - это первое законодательное закрепление давно начавшегося процесса, который называют по-разному - сближение публичного и частного права, публицизация частного права, приватизация публичного права, федерализация и конститулизация МЧП.

В немецкой доктрине МЧП методы коллизионного права были специально разработаны для права социального обеспечения и административного права. В работах немецких ученых утверждается, что коллизионные нормы для административного права (включая возможность применения иностранного права) отличаются от коллизионных норм, предназначенных для определения компетентного частного права (хотя они и могут черпать вдохновение из последних). Предлагается построение целостной системы коллизионных норм административного права. Высказывается мысль, что развитие коллизионных норм за пределами частного права означает 
рост МЧП, рассматриваемого в качестве коллизионного метода. В современной российской литературе отмечается, что закрепление в национальных кодификациях МЧП института применения иностранных публично-правовых норм является одним из аспектов интернационализации МЧП. Возможность применения таких норм - полезное средство для противодействия негативным явлениям, которые препятствуют развитию международного гражданского оборота.

Проблема применения публично-правовых норм иностранного законодательства достаточно часто возникает в судебной практике (и очень часто применение таких норм соответствует интересам именно «местной» стороны, участвующей в процессе в своем национальном суде). В подтверждение можно привести весьма своеобразный пример из недавней российской судебной практики.

В мае 2007 г. Федеральная таможенная служба РФ (далее - ФТС) подала в Арбитражный суд г. Москвы иск к одному из крупнейших американских банков - The Bank of New York (дело № A40-24987/07). Адвокат ФТС заявил, что «с 1996 по 1999 гг. банком была организована незаконная схема легализации денежных средств за экспортируемые в РФ товары, в связи с чем Россия получила ущерб в 7,5 млрд долл.». При этом сумма иска составляла 22,5 млрд долл. Иск был предъявлен на основе американского права - Закона об организациях, подверженных рэкету и коррупции (Racketeer Influenced and Corrupt Organizations Act 1970 - RICO).

По мнению представителей банка, иск не имел законных оснований: RICO - это американский уголовный закон, не подлежащий применению за пределами США. Однако представители ФТС РФ утверждали, что закон содержит гражданско-правовые нормы (положения о гражданско-правовой ответственности), которые могут применяться иностранными судами, в том числе российскими, на основании российских коллизионных норм. Очевидно, что главная ценность RICO с точки зрения истцов и их адвокатов состояла в том, что с нарушителя взыскиваются убытки потерпевшего в тройном размере и судебные издержки (отсюда и сумма иска $-22,5$ млрд).

Летом 2008 г. в судебных заседаниях рассматривался вопрос, компетентен ли Арбитражный суд г. Москвы (как с точки зрения подсудности, так и с точки зрения применимого права) рассматривать иск на основе американского уголовного закона.

Роберт Блейки (основной автор RICO) дал показания от лица ФТС. Главный вывод, который следовал из его ответов: RICO имеет как уголовно-правовую, так и гражданско-правовую составляющие. Дело, которое рассматривается в России, является гражданским иском, а Закон не ограничен только территорией США. Российский арбитражный суд вполне может применить положения этого закона. Профессор права Гарвардского университета Алан Дершовиц также дал письменные показания в поддержку ФТС РФ. Он, в частности, утверждал, что не существует юридического запрета, чтобы иностранное (неамериканское) правительство подало гражданский иск на основе RICO в иностранный суд. Ричард Торнбург (бывший генеральный прокурор и министр юстиции США) дал показания в пользу банка. Он доказывал, что в данном случае гражданский иск, поданный на основе RICO, безоснователен, однако Торнбург не утверждал принципиальной неприменимости норм RICO в российском суде.

RICO - это федеральный уголовный закон США, принятый в 1970 г. Основной целью его принятия была борьба с организованной преступностью. Помимо уголовно-правовых норм, закон включает положения о гражданской ответственности. Изначально предполагалось, что гражданско-правовые нормы будут играть вспомогательную роль. Однако положения о возмещении убытков в тройном размере и судебных издержек оказались чрезвычайно привлекательными для многих истцов и адвокатов. В 1980-е гг. произошло резкое увеличение числа гражданских исков, основанных на RICO. В настоящее время их число многократно превышает число уголовных дел, основанных на RICO.

К большому «сожалению» специалистов по МЧП, в октябре 2009 г. ФТС и BoNY решили спор в досудебном порядке. ФТС от иска отказалась, банк заявил, что не возражает, и Арбитражный суд удовлетворил ходатайство истца об отказе от иска. Ввиду этого вопрос о возможности применения иностранных публично-правовых норм в российском суде так и остался чисто те- 
оретическим. Однако сами факты предъявления иска на основе таких норм, приема подобного искового заявления и проведения слушаний о компетенции суда рассматривать этот иск представляют большой интерес, как с научной, так и с практической стороны.

В связи с возможностью применения в рамках коллизионного метода МЧП иностранных публично-правовых норм возникают проблемы: должно ли законодательство о МЧП закреплять специальное установление о применении иностранных публично-правовых норм или такое применение может следовать по умолчанию? Нужно ли законодательно определять круг таких норм или оставить это на усмотрение суда? Нужно ли специально выделять «административные коллизионные нормы», «налоговые коллизионные нормы», «уголовно-правовые коллизионные нормы»? Может ли максимальная детализация объема коллизионных норм быть одним из способов решения этой проблемы?

Представляется, что публично-правовые установления могут быть причислены к подлежащим применению сверхимперативным нормам иностранного права, если закон страны суда прямо не исключает возможность применения иностранных публичных предписаний, и последствия применения данных норм не противоречат публичному порядку соответствующего государства.

Что касается эволюции института автономии воли сторон, то российский законодатель в ст. 1186 ГК РФ не называет соглашение сторон методом или источником МЧП. Одновременно в п. 5 ст. 13 АПК РФ, устанавливающей перечень нормативных актов, применяемых при рассмотрении дел, закреплено, что государственный арбитраж применяет нормы иностранного права, в том числе, и в соответствии с соглашением сторон. Таким образом, в российском МГП автономия воли позиционируется как источник МЧП. Данное противоречие представляет собой типичную издержку межотраслевой кодификации МЧП.

В российском законодательстве о МЧП автономия воли - это только одна из коллизионных привязок. Автономия воли применяется только в договорных отношениях. Основная норма закреплена в ст. 1210 ГК РФ «Выбор права сторонами договора». Содержание автономии воли:
- Выбор применимого права не органичен «территориально»: избранное сторонами право может не иметь никакой связи с правоотношением.

- Выбор применимого права может быть сделан при заключении договора или в последующем.

- Выбор применимого права, сделанный после заключения договора, имеет обратную силу и считается действительным с момента заключения договора. По поводу этой нормы ВАС РФ вынес определение, что российское коллизионное регулирование допускает изменение применимого к договору права, и такое изменение будет иметь обратную силу, если не причиняет ущерба правам третьих лиц (Определение от 6.06.2012 г. № ВАС-3227/12).

- Выбранное право применяется к возникновению и прекращению любых вещных прав на движимое имущество без ущерба для прав третьих лиц.

- Выбор применимого права должен быть явно выражен или определенно вытекать из условий договора и обстоятельств дела (т.е. допускается «презюмируемая» воля сторон). В определении ВАС РФ от 26.01.2012 г. (№ BAC-16010/11) закреплено, что прямым выражением воли сторон о выборе применимого права является указание в договоре на применение нормативных актов или законодательства государства. При этом выбор российского права не исключает применения к договорным отношениям норм Венской конвенции ООН о договорах международной купли-продажи товаров 1980 г.

- Стороны договора могут выбрать применимое право как для договора в целом, так и для отдельных его частей (кумулятивный выбор применимого права).

- Если из совокупности обстоятельств дела на момент выбора применимого права следует, что договор реально связан только с одной страной, то выбор права другой страны не может затрагивать действие императивных норм права страны, с которой договор реально связан.

- Стороны договора могут выбрать право, применимое к иным (т.е. недоговорным) отношениям. 
Автономия воли допускается и по отдельным аспектам брачно-семейных отношений, связанных с иностранным правопорядком. При заключении брачного договора или соглашения об уплате алиментов супруги, не имеющие общего гражданства или совместного места жительства, могут избрать законодательство, применимое для определения их прав и обязанностей (ст. $161 \mathrm{CK}$ РФ). К сожалению, в практике российских судов общей юрисдикции применение иностранного права представляет собой редкое явление. В частности, нет ни одного примера применения ст. 161 СК РФ. В основном иностранное право применяется по делам, связанным с иностранным усыновлением, но эта практика является закрытой; кроме того, в таких делах нет места для автономии воли.

Применение иностранного права представляет собой регулярную практику международного коммерческого арбитража и государственных арбитражных судов. Однако в определении ВАС РФ от 30.06.2011 г. (№ ВАС-6417/11) отмечается отсутствие единообразия в практике применения ст. 1210 ГК РФ. В практике государственных арбитражных судов первой, апелляционной и кассационной инстанций встречаются случаи необоснованного отказа от применения иностранного законодательства.

Президиум ВАС РФ своим постановлением от 4.10.2011 г. (№ 6417/11) отменил в порядке надзора постановление Девятого арбитражного апелляционного суда и постановление Федерального арбитражного суда Московского округа по спору между AO «Parex banka» (г. Рига, Латвийская Республика) и АО «Универмаг «Москва»» (г. Москва, РФ). В постановлении Президиума ВАС РФ отмечалось, что суды апелляционной и кассационной инстанций применили к правоотношениям сторон нормы российского права. В п. 12 договора между «Parex banka» и «Универмагом «Москва»» было указано, что к поручительству применяются правовые акты Латвийской Республики. Применяя российское право, суд апелляционной инстанции счел, что стороны при заключении договора не выбрали применимое право, поскольку указание в п. 12 договора на применение правовых актов Латвии не является соглашением сторон о применимом праве. По мнению Президиума ВАС РФ в договоре между
«Parex banka» и «Универмагом «Москва»» прямо выражена воля сторон о выборе применимого права, поскольку стороны определенно указали применение нормативных актов Латвии. Какихлибо специальных требований к терминологии, используемой в оговорке о применимом праве, закон не предусматривает. Ввиду этого судебные акты апелляционной и кассационной инстанций нарушают единообразие в толковании и применении арбитражными судами норм ст. 1210 ГК РФ.

В практике встречаются случаи, когда суды и не пытаются выяснить вопрос о компетентном законодательстве, а автоматически применяют российское право. Федеральный арбитражный суд Московского округа в кассационном производстве постановлением от 25.07.2012 г. отменил определение Арбитражного суда г. Москвы и постановление Девятого арбитражного апелляционного суда по спору между «Петрофф-банк» (г. Москва, РФ) и Gazprombank (Switzerland). Суд кассационной инстанции отметил, что при определении характера правоотношений между «Петрофф-банк» и Gazprombank суды первой и апелляционной инстанций руководствовались исключительно нормами российского права и не учли особенностей правового регулирования операций по банковским счетам в швейцарском банке, установленного швейцарским законодательством. Однако при разрешении спора в силу ч. 1 ст. 133 АПК РФ и с учетом судебной практики суды должны в обязательном порядке определять нормы права, в том числе иностранного, подлежащие применению (в соответствии с правовой позицией Президиума ВАС РФ, выраженной в постановлениях от 04.10.2011 № 6417/11 и от 21.02.2012 № 2360/11). Суд кассационной инстанции подчеркнул, что при новом рассмотрении суду необходимо определить правовую природу оспариваемой сделки, соответственно, подлежащие применению нормы права: российского или швейцарского.

В контрактах автономия воли сторон выражается по-разному - употребляются терминологические конструкции: «споры и разногласия подлежат рассмотрению в соответствии с законодательством РФ» и «при рассмотрении споров применяется материальное право РФ». Практика показывает, что коммерческий арбитраж проводит содержательное отличие между этими терминологическими конструкциями. 
Например, в решении МКАС ТПП РФ от 4.08.2009 № 136/2008 указано: стороны Контракта согласовали, что «в споре они руководствуются требованиями Контракта, заявки, норм «Инкотермс 2000» и Правилами международной торговли на базе Венской конвенции с применением норм российского права». Поскольку стороны согласовали применение норм российского права, то состав арбитража констатировал, что к отношениям сторон подлежит применению Венская конвенция ООН о договорах международной купли-продажи товаров (1980), так как согласно п. 4 ст. 15 Конституции РФ международные договоры РФ являются составной частью ее правовой системы. Российское право арбитраж счел применимым в качестве субсидиарного статута.

Иной пример. В решении МКАС ТПП РФ от 22.122008 № 83/2008 по спору между Фирмой, имеющей местонахождение на территории ФРГ, и ЗАО, имеющим местонахождение на территории РФ, указано, что согласно п. 9.2 Контракта, заключенного между сторонами, «все споры и разногласия подлежат рассмотрению в соответствии с законодательством РФ». По мнению арбитража, несмотря на то, что и Германия, и Россия являются участницами Венской конвенции, стороны в качестве применимого права определили не правовую систему в целом, а «законодательство» РФ, т.е. только ту часть российской правовой системы, которая включает в себя нормативные акты, регулирующие гражданско-правовые отношения внутри страны, и не охватывает международные договоры РФ.

В заседании МКАС представители Истца по вопросу о применимом праве пояснили, что, употребляя в Контракте термин «законодательство», а не «право» РФ, стороны имели в виду законодательство в широком смысле, т.е. правовую систему в целом, включая действующие для России международные договоры; стороны не преследовали цель исключить применение к их отношениям Венской конвенции. Однако представитель Ответчика заявил, что Венская конвенция не должна применяться к отношениям сторон, поскольку стороны подчинили свои отношения по Контракту нормам российского законодательства.

С учетом текста Контракта и объяснений Ответчика МКАС посчитал, что стороны своим соглашением исключили применение к их от- ношениям Венской конвенции, и признал, что к отношениям сторон по Контракту подлежат применению нормы законодательства РФ.

Приведенные примеры показывают, что оговорка о применении «российского права» приводит к применению Венской конвенции ООН о договорах международной купли-продажи товаров, а оговорка о применении «российского законодательства» исключает ее применение. Однако такая практика не является единообразной.

В решении МКАС ТПП РФ от 24.07.2006 № 40/2005 по спору между Компанией, имеющей местонахождение на территории Франции, и Фирмой, имеющей местонахождение на территории США, указано, что в Контракте, в связи с которым возник спор, было предусмотрено: «При рассмотрении споров применяется материальное право РФ». Коммерческие предприятия сторон находятся в государствах-участниках Венской конвенции; согласно принципу автономии воли применимым является право государства-участника Венской конвенции - Российской Федерации. Вместе с тем в Контракте было определено, что «все другие положения, условия и правила определяются в соответствии с GAFTA 49». Типовой контракт GAFTA 49 (Международная ассоциация торговли зерном и кормами; Проформа № 49 действительна с 1.03.2000) в ст. 25 устанавливает, что «не применяется к настоящему контракту Конвенция ООН 1980 г. о договорах международной купли-продажи товаров».

В ходе заседания представитель Истца пояснил, что в связи со сделанной отсылкой к типовому контракту GAFTA 49 применение Венской конвенции следует считать прямо исключенным по соглашению сторон. Одновременно представитель Истца отметил, что Контрактом выбрано в качестве применимого российское право. Состав арбитража пришел к выводу, что в силу положений Контракта и типового контракта GAFTA 49 спор подлежит разрешению на основании материального права РФ без применения Венской конвенции.

Автономия воли может быть не только прямо выраженной, но и подразумеваемой. В качестве примера установления презюмируемой воли сторон можно привести решение МКАС ТПП РФ от 10.10.2007 № 12/2007 по спору между Фирмой, имеющей местонахождение на территории Италии, и ООО, имеющим местонахождение на 
территории РФ. В Контракте стороны не определили право, применимое к их отношениям. Истец настаивал на применении норм российского права, мотивируя это тем, что стороны в своих взаимоотношениях ссылались на нормы российского права, в переписке и в переговорах всегда исходили из применимости российского права. Ответчик в заседании МКАС согласился с тем, что спор должен рассматриваться по российскому праву.

$\mathrm{C}$ точки зрения арбитража, из совокупности обстоятельств дела однозначно вытекало, что стороны на основе принципа автономии воли осуществили выбор применимого права после заключения Контракта, и этот выбор действителен с момента его заключения. МКАС признал, что к отношениям сторон подлежат применению положения Венской конвенции, а в части, не урегулированной Конвенцией, - нормы материального права РФ.

В целом практика российского государственного и коммерческого арбитража демонстрирует положительное отношение к автономии воли сторон и применению иностранного права. Однако (как это ни парадоксально звучит) регулярное применение иностранного права в этих органах вызвано такой нормой российского права, которая в доктрине подвергается серьезной критике. В ст. 1191 ГК РФ «Установление содержания норм иностранного права» говорится, что по требованиям, связанным с осуществлением сторонами предпринимательской деятельности, бремя установления содержания норм иностранного права может быть возложено судом на стороны. По общему правилу, именно стороны, а не суд в спорах из предпринимательской деятельности устанавливает содержание иностранного права, что и предопределяет его применение.

Жереми Эйманн в своих докладах по теме «Федералистский подход к международному частному праву» обратил внимание, что если государства объединяются в союз на принципах федерализма, то предстоит решить вопрос: как будет регулироваться соотношение частных интересов и множественности правовых систем как на межгосударственном (т.е. в отношениях между субъектами федерации, в рамках образованного союза государств), так и на международном уровнях. Может ли объединение государств привести к так называемой конкуренции компетенции между федерацией и ее субъектами в сфере МЧП, или, напротив, оно создает систему, в рамках которой иерархия отношений между федерацией и ее субъектами наделяет федерацию верховной властью и исключительной компетенцией в отношении урегулирования указанного вопроса?

В данной области особо показательным является пример США, где вопрос по поводу разграничения компетенции между федерацией и ее субъектами возникает достаточно часто. Однако стоит сказать, что четкий и однозначный ответ на данный вопрос найти крайне сложно, поскольку создание государствами интеграционного объединения приводит к формированию своеобразного «клубка правовых систем», распутать который очень трудно. Тем не менее, стоит полагать, что данная проблема свойственна федерализму и различным значениям, которые может принимать данный термин. Если говорить точнее, основная сложность заключается в том, что федерализм является, прежде всего, идеей, системой политической организации, которая в институциональном отношении может выражаться в различных формах, но подчиняющийся, тем не менее, одной закономерности: поиску единства, совместимого с определенным разнообразием.

Выражаясь институциональным языком, данная закономерность принципиально означает, что создание политического союза государств не влечет прекращения существования суверенных государств. Являясь частями единого целого, государства, участвующие в подобном союзе, сохраняют при этом определенную политическую и юридическую автономию, степень которой в различных союзах неодинакова, однако может быть оценена исходя из способа разграничения компетенции между федерацией и ее субъектами.

Таким образом, главная цель исследования соотношения федерализма и МЧП состоит в поиске источника компетенции по предмету, преимущественно, в федеративном договоре (который чаще всего принимает форму Конституции) и какое именно публично-правовое образование - федерация или ее субъекты - наделено соответствующей компетенцией.

В США («живой лаборатории» федерализма), несмотря на то, что подобная компетенция может быть взята на себя федерацией, вопросы МЧП 
относятся к ведению штатов как в части регулирования отношений между штатами, так и в части регулирования отношений между США и третьими странами.

Что касается России, то в Конституции РФ прямо указано, что «федеральное коллизионное право находится в ведении Российской Федерации» (ст. 71, п. «о»), тем не менее, существует и совместная компетенция (ст. 72), в частности, трудовое и семейное право. Таким образом, не исключено возникновение интерлокальных коллизий, несмотря на то, что в любом случае федеральное законодательство будет обладать высшей юридической силой, нежели противоречащее ему законодательство субъектов РФ.

В рамках ЕС вопросы МЧП (между государствами-членами Союза, а также между государствами-членами и третьими странами) традиционно относились к компетенции каждого государства. Тем не менее, после вступления в силу Амстердамского договора от 2 октября 1997 г. (вступил в силу 1 мая 1999 г.), компетенция в данной области перешла к Союзу (ст. 81 ДФЕС - Договор о функичонировании Европейского Союза). Поскольку Союз не обладает исключительной компетенцией в данной области, а разделяет ее с государствами-членами, следовательно, то ссылаться на то, что законодательство Союза обладает высшей юридической силой, нельзя. Ввиду этого появляются многочисленные трудности. Можно назвать два типа подобных проблем: это, во-первых, вопросы действия в пространстве оснований для распространения компетенции каждого образования (государств-членов или ЕС в целом), во-вторых, это вопрос о разграничении областей применения каждого вида компетенции.

Амстердамский договор внес изменения в договоры об организации Европейских сообществ и посредством расширительного толкования ст. 67 и 81 ДФЕС (бывшие ст. 61, 65 и 67 Договора о Европейских сообществах) ЕС претендует на наличие у него компетенции по вопросам МЧП. Исходя именно из этих юридических оснований, были предложены и приняты различные «союзные» регламенты - «Брюссель І» (недавно измененный), «Брюссель II бис», «Рим I» и «Рим II».

Независимо от того, касаются ли они вопросов компетенции судов или применимого права, каждый из упомянутых регламентов считался способствующим установлению «согласованности норм, подлежащих применению, в государствах-членах в области коллизии законов и споров о подсудности». Между тем, производя унификацию норм о юрисдикционной компетенции (как в области гражданского и коммерческого права, так и в области семейного права и родительской ответственности) и коллизии законов (по вопросам договорного и внедоговорного права) государств-членов, представляется, что ЕС вышел за рамки своей компетенции. Представляется, что ЕС также нарушил принципы субсидиарности и пропорциональности, которые являются основополагающими принципами европейского права (ч. 3 и 4 ст. 5 Договора о EC). Таким образом, конституционность каждого регламента может быть оспорена, так же, как и их пространственная применимость.

В связи с этим можно ли считать, что Союз обладает некоторой компетенцией по регулированию частноправовых отношений, которые выходят строго за рамки межгосударственных? Этот крайне сложный вопрос (если предположить, что вопрос о конституционности регламентов когда-либо все-таки будет решен) должен получить детальный ответ.

Необходимо отметить, что МЧП в рамках ЕС в течение последних десятилетий постепенно закрепилось на конституционном уровне (если, конечно, считать, что Договор о ЕС и ДФЕС являются своего рода федеративной «конституцией»). Вопросы, которое оно регулируют, отныне также должны включать публичный аспект, делая привычное деление права на частное и публичное еще более относительным.

E.В. Постникова в своих докладах по теме «Федерализм в российском конституционном и международном частном праве» подчеркнула, что федерализм в международном частном праве - это комплексная тема, лежащая на пересечении публичного и частного права. Публичная составляющая здесь является главенствующей. Универсального определения федерализма не существует.

В российской науке конституционного права понятие федерализма, как правило, неразрывно связано с федеративным устройством государства и определяется, в частности, как способ (принцип) территориальной организации государства. 
Он выражен в характере взаимоотношений субъектов федерации между собой и федеральными органами государственной власти. В доктрине различают две основные модели федерализма - дуалистическая и кооперативная. В практике российского федерализма отчасти реализуются идеи кооперативного федерализма.

Однако, обращаясь к трудам зарубежных специалистов в области конституционного и международного права, а также учитывая тенденции развития экономической интеграции, выразившейся в широком распространении интеграционных объединений, возможно, понятие федерализма не следует полностью отождествлять лишь с формой территориального устройства государства. Следует также говорить о федерализме применительно и к некоторым международным организациям или межгосударственным объединениям.

В европейской и американской доктрине распространено мнение, что необходимо разграничивать понятия федерализма и федерации. Понятие федерализма касается лишь идей, ценностей концепций, а понятие федерации включает применение федерализма посредством различного институционального устройства в целях подчинения автономных единиц осуществляемой центральным правительством власти. Представляется целесообразным понимать федерализм в двух аспектах: конституционном и международном.

Несмотря на федеративное устройство РФ, федерализма как такового в российском международном частном праве практически не существует, особенно если сравнивать с федерализмом в США. О федерализме применительно к российскому МЧП можно условно говорить в двух аспектах. Один связан с применением российскими судами права стран с множественностью правовых систем, а второй - непосредственно с федеративным устройством РФ. Первый аспект, в отличие от второго, в полной мере относится к МЧП.

Когда речь идет о выборе российскими судами применимого права страны с множественностью правовых систем, т.е. страны, в которой существуют административно-территориальные образования со своими подсистемами права (федерации, унитарного государства с некоторыми элементами федерализма), то согласно ст. 1188 ГК РФ применяется правовая система, определяемая в соответствии с правом этой страны. Если невозможно определить, какая из правовых систем подлежит применению, то используется принцип наиболее тесной связи.

Что касается второго аспекта, то федеративное устройство РФ основано на ее государственной целостности, единстве системы государственной власти, разграничении предметов ведения и полномочий между органами государственной власти РФ и органами государственной власти субъектов РФ. Федерализм в российском МЧП выражается в урегулированности большей части вопросов на федеральном уровне и в приоритете федеральных законов перед правовыми актами субъектов Федерации. В российской правовой доктрине высказываются различные точки зрения по поводу федеративной природы РФ, как ни парадоксально это звучит. Одной из причин практически полярных точек зрения является то, что сферы ведения субъектов РФ являются чрезвычайно ограниченными. В частности, это явно видно в отношении вопросов, входящих в сферу МЧП.

Большинство российских исследователей понимают коллизионное право как совокупность норм, разрешающих коллизии между законами различных государств («внешнее») или нормативными актами одного государства («внутреннее»). В ч. «п» ст. 71 Конституции РФ закреплено, что «федеральное коллизионное право» относится к исключительному ведению Федерации. Однако здесь подразумеваются не коллизионные нормы в понимании МЧП, а правила применения на территории одного субъекта Федерации законодательства других субъектов РФ и общефедерального законодательства. Термин «федеральное коллизионное право» не имеет непосредственного отношения к МЧП, поскольку не включает коллизионные нормы по смыслу раздела VI «Международное частное право» ГК РФ, а с точки зрения российского гражданского законодательства МЧП отождествляется именно с коллизионным правом.

Относительно содержания термина «федеральное коллизионное право» среди российских ученых нет единого мнения. Федеральное коллизионное право определяют как совокупность 
закрепленных в Конституции РФ норм, на основе которых разрешаются споры о компетенции между Федерацией и субъектами. Согласно другому подходу, источниками федерального коллизионного права являются не только положения Конституции РФ, но и федеральное законодательство, регулирующее конституционно-правовые отношения в сфере разрешения коллизий; постановления КС РФ по вопросам своей компетенции. Профессор НИУ ВШЭ Ю.А. Тихомиров считает, что федеральное коллизионное право:

1. состоит из комплекса правовых идей и концепций, отражающих правовое опосредование устройства и функционирования Федерации;

2. включает материальные нормы, устанавливающие объем предметов ведения Федерации и ее субъектов и полномочия их органов;

3. вводит процедуры преодоления разногласий и разрешения споров между участниками коллизионных отношений;

4. допускает применение мер ответственности к участникам коллизионных отношений.

Ю.А. Тихомиров рассматривает федеральное коллизионное право как подотрасль коллизионного права, которую называет комплексной «суперотраслью права». По его мнению, конституционная формула «федеральное коллизионное право» является юридическим ориентиром и стимулом для формирования этой «суперотрасли права». Федеральное коллизионное право предназначено для предотвращения и устранения юридических противоречий в федеративных отношениях. Ученый предлагает очень широкое определение юридической коллизии. При этом традиционная трактовка юридической коллизии как столкновения норм не исчезает, но из единственной и универсальной становится одним из аспектов понятия. Коллизии в понимании МЧП составляют лишь часть более широкого понятия юридической коллизии.

Федеральное коллизионное право основывается на следующих принципах:

- признание федеральных органов государственной власти субъектами, регулирующими порядок принятия решений в коллизионных ситуациях;

- установление конституционного приоритета федерального закона либо нормативного пра- вового акта субъекта Федерации по основаниям ч. 5 и 6 ст. 76 Конституции РФ;

- допущение временного правового регулирования субъектами Федерации вопросов совместного ведения до принятия соответствующего федерального акта;

- установление правил перехода компетенции, когда в федеральном законе по предметам совместного ведения РФ и ее субъектов определяются порядок регулирования субъектами Федерации соответствующих вопросов и издание конкретизирующих законов;

- установление полномочий государственных органов Федерации и ее субъектов в связи с разрешением юридических коллизий;

- $\quad$ введение специальных процедур урегулирования разногласий и споров между органами государственной власти РФ и органами государственной власти ее субъектов;

- последовательное и поэтапное использование комплекса средств для преодоления разногласий и споров;

- $\quad$ определение режимов применения средств федерального вмешательства в сферу ведения субъектов Федерации и ее ограничения.

В российской доктрине существует и другой взгляд на основные конституционные принципы разрешения коллизий. Среди них выделяют:

- принцип приоритета прав и свобод человека;

- принцип приоритета федерального законодательства при соблюдении прав субъектов РФ; - принцип независимости арбитров, разрешающих споры;

- принцип конституционности и законности.

Органы государственной власти субъектов Федерации могут обращаться в Конституционный Суд РФ в связи с нарушениями их прав и законных интересов. По взаимному согласию федеральных органов государственной власти и органов государственной власти субъектов Федерации разрешение коллизионной ситуации может быть осуществлено путем:

a) изменения полномочий органов государственной власти и способов их взаимоотношений;

б) восстановления прежнего правового состояния в той или иной сфере внутрифедеральных отношений;

в) заключения новых или изменения ранее действовавших договоров и соглашений между 
федеральными органами государственной власти и органами государственной власти субъектов Федерации;

г) рассмотрения вопроса об изменении статуса субъекта Федерации в соответствии с ч. 5 ст. 66 Конституции РФ и федеральным конституционным законом.

Таким образом, формирование и использование федерального коллизионного права предполагает, прежде всего, реализацию конституционных положений в данной сфере.

Механизм разрешения коллизий между законодательством Федерации и субъектов закреплен, в частности, в Конституции РФ (ст. 4 и 76). Вопервых, Конституция РФ и федеральные законы имеют верховенство на всей территории РФ (ч. 2 ст. 4). Во-вторых, законы и иные нормативные акты субъектов РФ не могут противоречить федеральным законам, принятым по предметам исключительного ведения РФ и по предметам совместного ведения РФ и ее субъектов (ч. 5 ст. 76 Конституции РФ). Акт субъекта Федерации в этом случае утрачивает юридическую силу в части, противоречащей федеральному законодательству, и не подлежит применению. Но в случае противоречия между федеральным законом и нормативным правовым актом, изданным вне пределов ведения РФ по предметам ее совместного ведения с субъектами РФ, действует нормативный правовой акт субъекта РФ (ч. 6 ст. 76). Следует также учитывать роль доминирующего закона в отрасли. В качестве примера можно привести положения ГК РФ, согласно которому нормы гражданского права, содержащиеся в других законах, должны соответствовать указанному кодексу. В СК РФ закреплен приоритет норм СК перед нормами семейного права, содержащимся в законах субъектов Федерации.

В соответствии со ст. 71 Конституции РФ в исключительном ведении РФ находится, в том числе, гражданское, гражданско-процессуальное и арбитражно-процессуальное законодательство, правовое регулирование интеллектуальной собственности. В рамках исключительной сферы ведения РФ интерлокальные коллизии (между правовыми актами различных субъектов РФ) возникать не могут. Последние могут иметь место лишь в сферах, относящихся к совместному ведению федерации и субъектов (с учетом приоритета федерального законодательства) и к самостоятельному ведению субъектов. Интерлокальные коллизии могут иметь место лишь в сферах, относящихся к совместному ведению федерации и субъектов (с учетом приоритета федерального законодательства) и к самостоятельному ведению субъектов. Согласно ст. 73 Конституции РФ субъекты обладают всей полнотой государственной власти вне пределов исключительного ведения РФ, а также полномочий РФ по предметам совместного ведения. Однако Конституция не содержит механизма разрешения коллизий между правовыми актами субъектов, и на региональном уровне четких правил разрешения подобных коллизий, касающихся вопросов, входящих в сферу МЧП, не существует. В связи с этим возникает необходимость использовать аналогию права и закона.

В статье 72 Конституции РФ закреплены сферы совместного ведения РФ и ее субъектов, среди которых социальная защита, включая социальное обеспечение; трудовое, семейное, земельное законодательство, выполнение международных договоров РФ. В этих областях возможно возникновение интерлокальных коллизий вне сферы, урегулированной Федерацией. Но в рамках совместного ведения большая часть вопросов, входящих в сферу МЧП, регулируется на федеральном уровне за редкими исключениями.

Например, СК РФ устанавливает право субъектов РФ в своих нормативных правовых актах определять:

порядок и условия, при наличии которых вступление в брак в виде исключения и с учетом особых обстоятельств может быть разрешено до достижения 16 лет (ст. 13);

запрет присоединения к фамилии одного супруга фамилии другого супруга (ст. 32);

порядок осуществления права ребенка на имя и отчество (ст. 58);

возможность передачи детей, оставшихся без попечения родителей, в патронатную семью (ст. 123);

порядок учета лиц, желающих усыновить детей (ст. 126);

порядок и размер денежных средств, на которые имеют право дети, находящиеся под опекой или попечительством (ст. 148);

в договоре о приемной семье - размер вознаграждения, причитающегося приемным родителям, 
размер денежных средств на содержание каждого ребенка, меры социальной поддержки, предоставляемые приемной семье в зависимости от количества принятых на воспитание детей (ст. 153.1).

По этим вопросам могут теоретически возникать коллизии между правовыми актами субъектов РФ, для разрешения которых может использоваться привязка к праву постоянного места жительства.

Что касается брачного возраста, то около 30 субъектов РФ издали законы, которые закрепляют возможность для лиц, не достигших 16-летнего возраста, вступить в брак. При этом некоторые субъекты устанавливают минимальный возраст вступления в брак - 14 лет, а некоторые - 15 лет. Например, СК Республики Татарстан установил, что в виде исключения при наличии особых обстоятельств может быть разрешено вступление в брак лицам в возрасте от 14 до 16 лет, имеющим место жительства в Республике Татарстан. Согласно СК Татарстана, а также Закону Московской области «О порядке и условиях вступления в брак на территории Московской области лиц, не достигших возраста 16 лет», особыми обстоятельствами, дающими право на получение разрешения на вступление в брак лицу, не достигшему 16 лет, являются беременность, рождение общего ребенка у граждан, желающих вступить в брак, непосредственная угроза жизни одной из сторон. В других субъектах в качестве особых обстоятельств также признаются призыв жениха на службу в Вооруженные Силы РФ и другие чрезвычайные обстоятельства. Закон Мурманской области помимо условий, установленных в СК РФ, закрепляет некоторые особые условия вступления в брак:

согласие родителей, усыновителей, попечителей, других законных представителей несовершеннолетних, пожелавших вступить в брак;

заключение органа опеки и попечительства об отсутствии установленных СК РФ препятствий для вступления в брак и условиях для совместной жизни несовершеннолетних, пожелавших вступить в брак.

В СК Башкортостана минимальный возраст, при достижении которого лица могут заключать брак при наличии уважительных причин, не закреплен, и перечень особых обстоятельств является открытым.
Что касается права выбора супругами фамилии, то в Татарстане допускается присоединение фамилии супруга (двойная фамилия), а также с учетом национальных традиций при заключении брака супруги по своему желанию могут выбрать усеченный вариант либо сокращенную форму фамилии одного из них.

Статья 6 Трудового кодекса РФ закрепляет правомочие субъектов РФ принимать акты, содержащие нормы трудового права, по вопросам, не урегулированным федеральным законом. Например, правовыми актами субъектов может быть определен порядок осуществления прав и обязанностей работодателя в трудовых отношениях: органами управления юридического лица (организации) или уполномоченными ими лицами (ст. 20 ТК РФ). В случае коллизий применимое право определяется на основе lex loci laboris.

Интерлокальные коллизии могут возникать также в сфере инвестиционного законодательства. Такие коллизии разрешаются на основе принципа наиболее тесной связи.

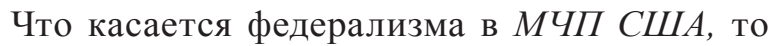
Конституция США в ст. 6 закрепляет верховенство федерального права по сравнению с правом штатов, а Десятая поправка устанавливает остаточную компетенцию штатов. Однако полномочия в законодательной сфере у федерации являются гораздо более ограниченными, чем полномочия штатов. Строго говоря, не существует общего американского коллизионного права, так как у каждого штата есть свое коллизионное право. На федеральном уровне действует лишь акт рекомендательного характера - Второй свод законов о конфликте законов (1971). Несмотря на то, что каждый штат вправе разработать свое собственное коллизионное законодательство, не все это сделали и большая часть американского коллизионного права отражена в прецедентной практике.

Конституция США создает условия для возникновения четырех различных категорий коллизий (конфликтов законов): между федеральным правом и правом штата (вертикальный конфликт); федеральным правом и иностранным правом; правовыми порядками штатов; правом штата и правом другого государства. Отметим, что процесс разрешения коллизий между федеральным американским законодательством и иностранным 
правом в основном разрешен в федеральных законах США. Теоретически разрешение всех четырех типов конфликтов должно относиться к компетенции Федерации. Однако на практике так происходит лишь с первыми двумя типами конфликтов.

В случае коллизии между законодательствами штатов федеральный судья должен определить применимое право на основании коллизионных норм штата, в котором он находится. Сам по себе этот факт не отличает американское коллизионное право от коллизионного права государств с множественностью правовых систем. Достаточно специфической чертой американского федерализма является имплементация Второго свода в правовую систему штатов и решение коллизионных проблем на его основе.

В качестве примера подобной методологии разрешения коллизий можно привести дело Kipin Industries Inc. v. Van Deilen International Inc. (1999). Дело касалось положения договора о праве удержания имущества до уплаты долга (lien-waiver). Сторонами было выбрано право штата Мичиган, согласно которому удержание имущества до уплаты долга являлось незаконным. В соответствии с законодательством этого штата подобное обременение (ограничение права) противоречит публичному порядку штата. Федеральный судья должен был применить коллизионное право штата местонахождения суда, т.е. Мичигана. По Второму своду (пар. 187, 188) выбор сторонами применимого права рассматривается как ошибка в случае, если согласно выбранному праву соответствующее положение договора является недействительным. Если данное положение будет действительным в соответствии с правом штата, право которого применялось бы в отсутствие автономии воли, то ошибочный выбор права должен игнорироваться. Суд применил данное положение Свода, и сам определил право, применимое в отсутствие автономии воли сторон. На основании специальной нормы, закрепленной в пар. 196 Второго свода, в отношении предоставления услуг, которые оказывались в штате Кентукки, Суд пришел к выводу, что следует применять право Кентукки. В соответствии с правом этого штата положения договора о праве удержания имущества до уплаты долга было действительным.
Рассмотрим международный аспект фе-

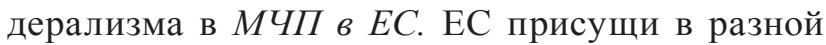
пропорции элементы как международной организации, так и конфедерации и даже федерации. Высказывается точка зрения, что в рамках ЕC процесс федерализации находится на стадии становления, и в результате была сформирована совокупность институтов, образующих комплексную правительственную структуру с еще не определившейся природой: федеративной или конфедеративной. В российской и зарубежной доктрине многие ученые квалифицируют ЕС как международную организацию, обладающую элементами наднациональности.

С определенной долей условности можно говорить об элементах федерализма в ЕС, в частности, применительно и к МЧП. Международный аспект федерализма выражается, например, в основных свободах и в гражданстве ЕС. Кроме того, следует отметить прямое действие правовых норм права ЕС. Подобной характеристикой обладают положения Договора о функционировании ЕС, касающиеся основных свобод внутреннего рынка, и регламенты ЕС. Следует обратить внимание на такой принцип либерализации трансграничных экономических отношений, как принцип взаимного признания, который служит инструментом разрешения коллизий между законодательствами государств-членов ЕС. Принцип «взаимного признания» во многом сходен по содержанию с так называемой «торговой (коммерческой) оговоркой» в США, которая служит правовым инструментом, обеспечивающим свободу торговли между штатами.

Представляется, что можно выделить два типа коллизий: с одной стороны, коллизии между законодательствами государств-членов в рамках ЕC, а с другой - «подлинные» международные коллизии. Первые разрешаются на основании МЧП ЕС в отношении вопросов, по которым приняты соответствующие акты (регламенты). «Подлинные» международные коллизии разрешаются двумя способами. Первый способ - применение коллизионных норм, выработанных национальным законодателем или закрепленных в международных соглашениях (например, Франция, Дания). Второй способ - применение коллизионных норм регламентов ЕС во взаимоотношениях с лицами из стран - не членов ЕС путем прямой отсылки 
к регламентам в национальном законодательстве по МЧП (ФРГ, Австрия, Польша).

Подводя итог, следует отметить, что о федерализме в МЧП все же следует говорить условно, как с точки зрения конституционного, так и международного аспектов.

По второму направлению исследования «Специфика применения иностранного права в условиях глобального финансового и экономического кризиса» с докладами выступили:

Давид Шилштейн в своих докладах по теме «Уголовная ответственность корпораций» проанализирован институт уголовной ответственности юридических лиц и проблему статуса иностранных юридических лиц как субъектов наказания во французском уголовном праве

Возможность привлечения юридических лиц к уголовной ответственности появилась во французском праве сравнительно недавно - в 1994 году после вступления в силу новой редакции Уголовного кодекса Франции. Целью данной реформы было, в том числе, облегчение положения руководителей предприятий, которые систематически привлекались к уголовной ответственности за правонарушения, о совершении которых они даже не догадывались (например, за несчастные случаи на производстве).

С технической точки зрения речь идет о «косвенной» уголовной ответственности или ответственности «через представителя». Юридическое лицо само по себе не совершает правонарушения, однако юридическому лицу могут вменяться правонарушения, совершенные в его пользу его руководителями. Именно этот смысл заложен в ст. 121-2 УК Франции, согласно положениям которой «юридические лица подлежат уголовной ответственности за преступные деяния, совершенные в их пользу их органами или представителями юридического лица». Из этого следует, что преступление, совершенное работником организации, не влечет уголовной ответственности организации - работодателя, если только сотрудник не действовал по приказу, полученному от руководства организации. Следует отметить, что привлечение к уголовной ответственности государства и органов местного самоуправления не допускается, если последние выполняют функции публично-правового характера (неделегируемые полномочия).
Что касается круга преступлений, за совершение которых юридические лица могут привлекаться к уголовной ответственности, то с момента принятия Закона Пербена-2 (2004) он охватывает все без исключения преступления, предусмотренные уголовным законодательством Франции.

Привлечение юридического лица к уголовной ответственности не исключает привлечения к уголовной ответственности и его директора физического лица. Иными словами, с юридической точки зрения, юридическое лицо не несет ответственность за действия физического лица. Таким образом, юридически это не является истинной «замещенной» уголовной ответственностью. На практике руководители предприятий привлекаются к уголовной ответственности за виновные противоправные деяния (например, дачу или получение взятки, легализацию денежных средств, полученных преступным путем, дискриминацию и т.д.).

Вопрос о том, можно ли на территории Франции привлечь к уголовной ответственности иностранное юридическое лицо, остается открытым. Формально законом это прямо не запрещено, однако на сегодняшний день в практике французских судов нет ни одного случая привлечения к уголовной ответственности иностранного юридического лица.

Мнения французских ученых-юристов по данному вопросу разделились. Некоторые авторы (например, Мирей Делма-Марти) считают, что привлечение к уголовной ответственности иностранных юридических лиц более чем возможно. В пользу данного мнения может говорить то, что невозможность привлечения к уголовной ответственности иностранных юридических лиц ставила бы французские юридические лица в неравное положение по отношению к иностранным. Так, например, установление господства над рынком в результате дачи взятки как во Франции, так и за ее пределами влекло бы уголовную ответственность для французских юридических лиц, а иностранным юридическим лицам, совершившим то же преступление, было бы нечего бояться.

К тому же, французские юридические лица, имеющие «судимость», находятся в менее выгодном положении при участии в тендерах (если, конечно, участие в тендерах не было запрещено приговором суда в качестве дополнительного 
наказания). Одновременно иностранные юридические лица имеют возможность выиграть тендер, даже если в прошлом они были замечены в коррупционных действиях и заслуживают, с точки зрения французского права, уголовного наказания. Эти аргументы являются достаточно важными, однако не могут свидетельствовать однозначно о правильности подобной точки зрения.

Правильной следует признать точку зрения тех авторов, которые считают, что привлечение к уголовной ответственности иностранных юридических лиц во Франции не предусмотрено законом. Прежде всего, экономический аргумент, рассмотренный выше, не является обоснованным, поскольку, как представляется, французское предприятие, занимавшееся взяточничеством, вряд ли после этого вправе взывать к справедливости и говорить о равенстве между французскими и иностранными юридическими лицами.

К тому же возможность привлечения юридических лиц к уголовной ответственности появилась во Франции совсем недавно и до сих пор вызывает ряд вопросов. Навязывать этот принцип другим странам с другими правовыми системами, не предусматривающими уголовную ответственность юридических лиц, было бы не совсем правильным.

Наконец, вопрос об исполнении наказания в отношении иностранного юридического лица является чрезвычайно деликатным. Какие категории иностранных юридических лиц вообще могут привлекаться к уголовной ответственности? Что касается наказаний, то вправе ли французский судья приговорить иностранное юридическое лицо к ликвидации? В действительности у него нет для этого возможности. К настоящему моменту ни одно иностранное юридическое лицо не понесло уголовного наказания по приговору французского суда, более того, иностранные юридические лица даже ни разу не привлекались к уголовной ответственности.

Однако нынешнее положение вещей может измениться, поскольку практика Кассационного Суда недавно открыла для этого некоторые возможности. Постановление от 30 октября 2012 г. может толковаться как косвенное признание возможности привлечения иностранных юридических лиц к уголовной ответственности. Согласно обстоятельствам дела, фактический руководитель люксембургского общества был осужден за соучастие в незаконной деятельности в сфере автоперевозок. Формально данный рынок принадлежал французскому филиалу общества, но фактически деятельность осуществлялась люксембургским обществом, нарушавшим положения французского законодательства. В результате понес наказание только руководитель - физическое лицо, однако привлечен к уголовной ответственности и осужден он был как пособник люксембургского общества. Иначе говоря, даже если люксембургская компания не была привлечена к ответственности, то юридически именно она была реальным исполнителем преступления.

Однако не стоит преувеличивать значимость этого Постановления. Оно даже не было опубликовано. К тому же тот факт, что к уголовной ответственности был привлечен лишь руководитель, свидетельствует о некоторой нерешительности французских судов привлекать иностранные юридические лица к уголовной ответственности. Кассационный Суд (по свойственной ему привычке) отказался ясно выразить свою позицию по данному вопросу, хотя у него была такая возможность.

Возможно, изменения будут привнесены европейским уголовным правом. Действующие директивы ЕС оставляют на усмотрение государств-членов возможность привлекать юридические лица к уголовной или административной ответственности. На стадии обсуждения находится Директива о защите экономических интересов EC, декларирующая необходимость предусмотреть уголовную ответственность юридических лиц в случае совершения правонарушений. Эта Директива может позволить налагать на юридические лица уголовные санкции.

Если все же предположить, что принцип уголовной ответственности иностранных юридических лиц утвердится во французском праве, то следует уделить особое внимание вопросу о вменении преступления юридическому лицу. Эта проблема должна быть наиболее тщательно изучена, поскольку она составляет основное условие применения такой ответственности. Вопрос о вменении может быть представлен в двух различных формах: в простой форме, когда преступление совершено в рамках деятельности иностранной компании (прямое вменение); и в 
более сложной форме, когда преступление было совершено в рамках международной группы компаний. Здесь возникает проблема, может ли преступление, совершенное дочерней французской организацией иностранной материнской компании, быть вменено последней.

I. Прямое вменение (преступление совершено в рамках деятельности иностранной компании).

Для того, чтобы вменить преступление юридическому лицу, необходимо, чтобы оно было совершено для его «органа или представителя» (согласно ст. 121-2 УК Франции). Это не представляет сложности, если преступление совершено руководителем иностранной компании (фактическим или юридическим руководителем). Напротив, если преступление было совершено работником, оно не может быть вменено иностранной компании (например, если работник иностранной компании растратил в свою пользу деньги, которые ей предоставила французская компания). С другой стороны, проблема усложняется, когда преступление физически совершено работником по требованию руководства. В этом случае преступление может быть вменено компании. Единственный случай из судебной практики, признающий уголовную ответственность иностранного юридического лица, касался такой ситуации: испанский дорожный перевозчик использовал цистерны, предназначенные для продуктов питания, для перевозки нефти (предназначенной для производства смазочных материалов). Кроме того, он представлял подложные документы французских агропромышленных компаний, чтобы цистерны соответствовали французскому законодательству. Имел место обман в отношении качества предоставляемых услуг по поддельным документам (т.е. два состава преступления). Испанская компания подверглась уголовному наказанию во Франции.

В связи с этим можно сделать два вывода:

1. О самом принципе ответственности: Апелляционный суд постановил, «что иностранные юридические лииа могут быть признань уголовно ответственными за преступление, предполагающее использование подложных документов, совершенное во Франиии, в соответствии со статьей 441-2 Уголовного кодекса». Кассационный Суд не выразил несогласия с таким мнением.
2. О вменении преступления: Апелляционный суд определил, что «нарушение вписывалось, таким образом, в политику, в любом случае допускаемую компанией (испанской), чтобы, исходя из экономического интереса, не возврашать свои грузовики-ичистерны пустыми в Испанию». Таким образом, представляется, что преступление вписывается в политику компании и было совершено работником по требованию руководства, т.е. иностранное юридическое лицо может преследоваться по уголовному закону.

Значение решения Апелляционного суда представляется чрезвычайно важным. Любая иностранная компания, которая отправляет своего работника во Францию, чтобы предложить от своего имени вознаграждение за получение определенной доли рынка во Франции, может преследоваться за активную коррупцию.

В связи с этим возникает вопрос: необходимо ли, чтобы преступление было совершено именно во Франции? Представляется, что в целом такой необходимости нет. Французские полномочия по наложению ответственности основаны не только на территориальности преступления, но и на национальности лица, совершившего преступление, или его жертвы. Таким образом, даже если денежные средства были переданы за границей французскому гражданину в качестве взятки, Франция будет компетентна судить взяткодателя (т.е. иностранную компанию). В отдельных исключительных случаях имеет место другая ситуация, например, по вопросам подделки (нарушения авторских прав), нужно, чтобы преступление было совершено во Франции. Если французские песни нелегально (без оплаты авторских гонораров) размещены на российском сайте, отредактированном на русском языке и предназначенном для российской публики, невозможно преследовать компанию, которая использует сайт во Франции. В плане уголовного преследования необходимо действовать в России.

Интерес представляет также вопрос о перемещении во Францию денежных средств, добытых преступным путем. В случае, если иностранное образование (компания, орган местного самоуправления) поместило денежные средства, добытые преступным путем, на банковский счет во Франции, или приобрело имущество во 
Франции (движимое или недвижимое), возможно преследовать его за отмывание денежных средств. Преследование за данное преступление очень эффективно в том смысле, что оно позволяет привлекать к ответственности того, кто поместил денежные средства во Франции, даже если по преступлению, послужившему источником нелегальных денежных средств, истек срок привлечения к ответственности, и даже если французский судья не компетентен привлекать к ответственности лиц, совершивших это преступление. Именно посредством привлечения за отмывание денежных средств во Франции удается преследовать африканских руководителей компаний, которые либо растратили денежные средства иностранного государства (хищение государственных денежных средств), либо получили нелегальное вознаграждение (пассивная коррупция). Эта проблема известна во Франции под названием «дело о незаконно приобретенной собственности».

II. Косвенное вменение (уголовная ответственность материнской компании за преступления, совершенные ее дочерними компаниями).

Можно ли подвергнуть уголовному преследованию материнскую компанию за преступление, совершенное одной из ее дочерних компаний? Этот вопрос ставится в связи с необходимостью установить возможность уголовной ответственности за действия третьих лиц. Однако согласно ст. 121-1 УК Франции, «никто не подлежит уголовной ответственности иначе, как за свое собственное деяние». Речь идет о том, чтобы выяснить (с учетом специфики отношений между французской дочерней компанией и иностранной материнской компанией), могут ли преступления, совершенные дочерней компанией быть вменены материнской компании. При этом возможны различные ситуации.

Ситуация, при которой преступление вписывается в основную политику материнской компании. Эту гипотезу можно рассмотреть на примере, актуальном для Франции на сегодняшний день. Швейцарский банк (UBS) отдает своей французской дочерней организации распоряжение продвигать свои услуги клиентам во Франции в нарушение французского уголовного законодательства о продвижении банковских услуг. В этом деле не только французской дочерней компании, но и швейцарскому банку были предъявлены обвинения (они были подвергнуты уголовному преследованию). Однако на данный момент дело находится на стадии расследования.

Технически существует множество способов привлечь к ответственности материнскую компанию, в частности:

1) вменение ей преступления, вменяемого дочерней компании:

- в качестве соучастника (именно материнская компания приняла решение относительно этой политики агрессивного продвижения услуг);

- в качестве подстрекателя (т.е. по французскому праву, соучастие путем провоцирования): она подстрекает к совершению преступления (по смыслу ч.2 ст. 121-7 УК). Основная сложность здесь состоит в доказывании: как доказать, что принятие решения происходило в месте нахождения материнской компании? Это неочевидно и необходимо тщательно проанализировать ту автономию в принятии решений, которой располагала дочерняя компания;

2) использование отдельного преступления, подлежащего вменению только материнской компании (например, укрывательство, которое состоит в извлечении выгоды из знания о происхождении дохода от преступления, совершенного третьим лицом). Таким образом можно подвергнуть уголовному преследованию как французскую дочернюю компанию (за нарушение законодательства о продвижении банковских услуг), так и материнскую компанию (за укрывательство доходов от этого преступления - поскольку она укрывает денежные средства, полученные от преступления).

Ситуация, в которой материнская компания не приказывала совершить преступление, но позволила дочерней компании это сделать. В данной ситуации следует различать умышленные и неумышленные преступления.

Если преступление совершено умышленно по приказу руководства дочерней компании без ведома материнской компании, представляется невозможным привлечь последнюю к уголовной ответственности. Умышленное преступление предполагает психологическую связь с осуществленным противоправным актом. Если это знание отсутствует на уровне органов или представи- 
телей материнской компании, только дочерняя компания подлежит уголовному преследованию.

Тем не менее, однако, если в теории на обвинении лежит обязанность по доказыванию умысла, то на практике это знание в области уголовного права в коммерческих правоотношениях часто презюмируется. Считается, что субъект преступления «не мог не знать» о неправомерном характере совершенных действий. Но в принципе, такая ситуация привлечения к ответственности материнской компании уникальна.

По-другому ситуация складывается в случае совершения неумышленных преступлений. Уголовная ответственность иностранной материнской компании представляется возможной в случае совершения ее дочерней компанией неумышленного преступления. Если речь идет, например, о на 100\% дочерней компании, у которой материнская компания изымает денежные средства (как следствие, содержание оборудования становится невозможным, в результате чего имеет место несчастный случай, связанный с техническим дефектом), то можно предположить уголовную ответственность материнской компании как косвенного виновника нанесения ущерба (несчастного случая). Действительно, материнская компания в данном случае способствовала созданию ситуации, которая стала благоприятной для причинения ущерба, и очевидно не приняла мер, которые позволили бы его избежать.

С.А. Чеховская в своих докладах по теме «Проблемы корпоративного права в условиях глобального экономического кризиса» акцентировала внимание на вопросах модернизации корпоративного права и корпоративного управления в ЕС и в России и правовых ограничений участия иностранного инвестора в российских коммерческих организациях.

Корпоративное право в современный период является одной из наиболее динамичных правовых отраслей. В декабре 2012 года Европейская комиссия анонсировала «План действий: европейское корпоративное право и корпоративное управление - современная правовая основа для большей вовлеченности акционеров и устойчивости компаний». Из названия этого документа видны две главных цели реформирования европейского корпоративного права - обеспечение устойчивости компаний и вовлеченности акционеров в корпоративное управление. На пути к достижению данных целей видятся три главные проблемы:

- Краткосрочность (short-termism) статуса акционера. Эту проблему спровоцировал финансовый кризис. Краткосрочность любых инвестиций, недостаток «долгих» денег заставляют искать, в том числе, и правовые пути для ее решения, для обеспечения финансовой устойчивости компании. В частности, на Двенадцатой европейской конференции «Корпоративное право и корпоративное управление» (организованной Европейским институтом корпоративного управления 16-17 мая 2013 г. в Дублине) рассматривалась идея о том, чтобы различать объем прав акционеров не только в зависимости от пакета акций (в настоящее время различают статус миноритарных и мажоритарных акционеров), но и в зависимости от того, как долго акционер является держателем определенного пакета акций.

- Невовлеченность акционеров в корпоративное управление. Под вовлеченностью акционеров в управление компанией понимаются осуществление контроля за деятельностью компании, активные действия по использованию прав акционеров, включая право участие в общем собрании, право голоса, на информацию и др.

- Обеспечение прозрачности компании. Решение этой проблемы позволит акционерам обладать необходимой информацией о компании, что, в свою очередь, будет способствовать активному участию акционеров в управлении, т.е. предполагается, что будет решаться и проблема невовлеченности акционеров в корпоративное управление.

В Российской Федерации вопросы, касающиеся модернизации корпоративного права в целом, и правового обеспечения корпоративного управления, в частности, в современный период также находятся в центре профессиональных дискуссий. В целях улучшения правового обеспечения корпоративного управления 15 мая 2013 года Московской биржей и ОЭСР был организован технический семинар. Главная тема семинара - обсуждение проекта нового Кодекса корпоративного управления России. Это рекомендательный акт, который придет на смену ныне 
действующему Кодексу корпоративного поведения. Во Франции также существует подобный акт, который называется Recommandations sur le gouvernement d’enterprise. И российский Кодекс, и французские Рекомендации являются документами так называемого мягкого права, которые рекомендуются для добровольного применения, и, как правило, используются биржами для листингуемых акционерных обществ на основе принципа «применяй или объясняй» (comply or explain). Основными обсуждаемыми вопросами проекта Кодекса корпоративного управления были следующие:

- необходимость минимизации ассиметрии информации, которая существует прежде все между мажоритарными и миноритарными акционерами. Здесь мы видим, что общеевропейская проблема обеспечения прозрачности в системе корпоративного управления также актуальна и в России;

- принципы формирования Совета директоров акционерного общества, требования к составу этого органа, статус независимых директоров. Вопрос о роли Совета директоров не перестает быть актуальным с того момента, как начали обсуждаться проблемы корпоративного управления.

Следующий блок вопросов касается реформирования корпоративного законодательства. В России эта отрасль законодательства существенно изменилась после принятия Федерального закона № 47538-6/2 «О внесении изменений в главу 4 части первой Гражданского кодекса Российской Федерации, статью 1 Федерального закона «О несостоятельности (банкротстве)» и признании утратившими силу отдельных положений законодательных актов Российской Федерации». Российское законодательство определяет хозяйственные товарищества и общества как корпоративные коммерческие организации с разделенным на доли (вклады) учредителей (участников) уставным (складочным) капиталом. Статья 65.1. ГК РФ закрепляет, что юридические лица, учредители (участники, члены) которых обладают правом на участие в управлении их деятельностью (право членства), являются корпоративными организациями (корпорациями). Термины «корпорация», «корпоративный»в российском законодательстве используются в смысле, значительно отличающемся от американского законодательства.

Хозяйственные общества разделены на публичные и непубличные. К первым относятся акционерные общества, акции которых и конвертируемые в такие акции ценные бумаги публично размещаются (путем открытой подписки) или публично обращаются на условиях, установленных законами о ценных бумагах. Положения о публичных обществах применяются также к акционерным обществам, устав и фирменное наименование которых содержат указание на то, что общество является публичным. К непубличным обществам относятся общества с ограниченной ответственностью и акционерные общества, которые не отвечают признакам публичного общества (п. 1 и 2 ст. 66.3 Проекта ГК РФ).

Таким образом, в Российской Федерации идет активный процесс преобразований в сфере корпоративного права и корпоративного управления.

Правовое регулирование иностранных инвестиций в России включает как нормативные акты, регулирующие непосредственно деятельность иностранных инвесторов, так и акты, регламентирующие общий правовой режим инвестиционной деятельности и ее конкретных правовых форм. Основополагающим является положение ст. 2 ГК РФ, согласно которому правила, установленные гражданским законодательством, применяются к отношениям с участием иностранных граждан, лиц без гражданства и иностранных юридических лиц, если иное не предусмотрено федеральным законом.

Федеральный закон от 9 июля 1999 г. № 160Ф3 «Об иностранных инвестициях в Российской Федерации» (в ред. от 06.12.2011) направлен на гарантирование стабильности условий и обеспечение прав инвесторов на инвестиции, получаемые от них доходы и прибыль, а также защиту прав и интересов иностранных инвесторов. Однако, по сути, этот акт носит декларативный характер.

Участие иностранного инвестора в российской организации может осуществляться или в рамках вновь создаваемых юридических лиц, или путем привлечения иностранного капитала в уже существующие российские организации. Правовой порядок учреждения юридического лица с иностранными инвестициями не содержит ограничений, но имеет особенности. Речь идет 
о дополнительном документе, который предоставляется при государственной регистрации юридического лица. В соответствии со ст. 12 Ф3 от 08.08.2011 № 129-Ф3 (в ред. от 23.07.2013) «О государственной регистрации юридических лиц и индивидуальных предпринимателей» необходимо представить выписку из реестра иностранных юридических лиц соответствующей страны происхождения или иное равное по юридической силе доказательство юридического статуса иностранного юридического лица - учредителя.

Если обратиться к немногочисленной судебной практике, то можно сделать вывод, что суды встают на защиту регистрируемого юридического лица с иностранным участием, если регистрирующий орган требует дополнительные документы (например, отчет об оценке стоимости вклада в уставный капитал или другие документы). Регистрирующий орган не вправе требовать представления других документов, кроме документов, установленных законом.

В соответствии с п. 2 ст. 4 Федерального закона «Об иностранных инвестициях в Российской Федерации», изъятия ограничительного характера для иностранных инвесторов могут быть установлены федеральными законами только в той мере, в какой это необходимо в целях защиты основ конституционного строя, нравственности, здоровья, прав и законных интересов других лиц, обеспечения обороны страны и безопасности государства. Основные положения нормативных актов, устанавливающих такие ограничения:

1) Федеральный закон от 29.04.2008 № 57-Ф3 (в ред. от 16.11.2011) «О порядке осуществления иностранных инвестиций в хозяйственные общества, имеющие стратегическое значение для обеспечения обороны страны и безопасности государства» применяется к отношениям, которые связаны с осуществлением иностранными инвесторами инвестиций в форме приобретения акций (долей) хозяйственных обществ, имеющих стратегическое значение (далее - общества стратегического значения), и с совершением иных сделок, влекущих установление контроля иностранного инвестора над такими хозяйственными обществами, и которые возникли после дня вступления в силу этого Закона. Закон установил перечень видов деятельности, имеющих стратегическое значение для обеспечения обороны и безопасности РФ, который является закрытым и состоит из 42 наименований, например:

- деятельность, связанная с ядерными установками, ядерными материалами и радиоактивными веществами;

- $\quad$ деятельность по производству оружия, патронов и составных частей к ним, боеприпасов, взрывчатых материалов промышленного назначения;

- деятельность по обеспечению авиационной и космической безопасности;

- деятельность по теле- и радиовещанию на территории, где население составляет половину и более численности субъекта Российской Федерации;

- деятельность по обеспечению телефонной связи;

- геологическое изучение, разведка и добыча полезных ископаемых, добыча водных биологических ресурсов.

Для такого рода сделок Закон устанавливает специальный порядок их совершения: иностранный инвестор либо входящее в группу лиц юридическое или физическое лицо, которые намереваются совершить сделку, обязано подать в Федеральную антимонопольную службу РФ (ФАС РФ) ходатайство о предварительном согласовании такой сделки. ФАС РФ, в свою очередь, обязана получить заключения от Минобороны и ФСБ РФ, а в определенных случаях - заключение Межведомственной комиссии по защите государственной тайны. ФАС РФ направляет в Правительственную комиссию по контролю за осуществлением иностранных инвестиций в РФ (далее - Правительственная комиссия) указанные заключения, ходатайство и полученные в результате проведения проверок материалы, а также свои предложения относительно решения о предварительном согласовании сделки либо об отказе в таком согласовании. Срок рассмотрения ходатайства ФАС РФ и Правительственной комиссией не может превышать 3 месяца со дня регистрации ходатайства в ФАС до дня предварительного согласования сделки либо отказа в согласовании. В исключительных случаях срок рассмотрения ходатайства по решению Правительственной комиссии может быть продлен на 3 месяца. Если сделки совершаются с нарушением указанного порядка, они являются ничтожными. 
2) Ограничения для иностранных инвесторов действуют также на финансовых рынках, в частности, на страховых рынках.

Органом страхового надзора является Банк России. В Законе РФ от 27 ноября 1992 г. № 4015-1 «Об организации страхового дела в Российской Федерации» (в ред. от 23.07.2013) сокращен перечень запретов на осуществление отдельных видов страхования дочерними обществами иностранных инвесторов, а также страховыми организациями, имеющими долю иностранных инвесторов более $49 \%$ в своем уставном капитале. При этом количество запретов зависит от степени иностранного участия. Дифференциация запретов в зависимости от степени иностранного участия ограничена по времени. С 22 августа 2017 г. для всех иностранных организаций с иностранным участием будет установлен единый перечень запретов.

Ограничения устанавливаются в отношении следующих субъектов:

дочерние общества иностранных инвесторов; организации, имеющие долю иностранного инвестора в уставном капитале более $49 \%$, но не более $51 \%$;

организации, имеющие долю иностранного инвестора в уставном капитале более $51 \%$.

Данным организациям запрещено осуществлять отдельные виды страхования. Например, страхование жизни в настоящий момент не разрешается осуществлять всем страховым организациям с иностранным участием. Данный запрет не распространяется на организации, доля иностранного инвестора в уставном капитале которых более $49 \%$, но не более $51 \%$, а с 22.08 .2017 отменяется и в отношении всех остальных категорий страховых организаций с иностранным участием. Дочерним обществам иностранных инвесторов и организациям, имеющим значительную долю (более 49\%) иностранных инвесторов в уставном капитале, не нужно получать предварительного разрешения на открытие филиалов и участие в дочерних страховых организациях.

3) В банковской сфере Федеральным законом от 2 декабря 1990 г. № 395-1 (в ред. от 23.07.2013) «О банках и банковской деятельности» предусмотрен механизм установления размера (квоты) участия иностранного капитала в банковской системе РФ. Квота должна устанавливаться феде- ральным законом по предложению Правительства РФ, согласованному с Банком России. При достижении установленной квоты Банк России обязан прекратить выдачу лицензий на осуществление банковских операций банкам с иностранными инвестициями, филиалам иностранных банков. Кроме того, Банк России имеет право наложить запрет на увеличение уставного капитала кредитной организации за счет средств нерезидентов и на отчуждение акций (долей) в пользу нерезидентов, если результатом указанного действия является превышение такой квоты. В настоящее время квота участия иностранного капитала в банковской системе РФ не установлена и нет информации о проекте данного документа.

Таким образом, можно сделать вывод, что в тех сферах, где в настоящий момент закреплены жесткие ограничения для иностранных инвесторов, наблюдается тенденция либерализации регулирования. Специальные нормы, которые сейчас действуют для иностранных организаций на рынке ценных бумаг, также подтверждает эту тенденцию. Главным мотивом либерализации является создание инвестиционно привлекательного российского рынка ценных бумаг в соответствии с Поручением Президента РФ от 28 октября 2011 г. по созданию и развитию Международного финансового центра в РФ. Будем надеяться, что создание благоприятных условий для деятельности иностранных инвесторов на территории России будет продолжаться.

Этьен Пато в своих докладах по теме «Защита несовершеннолетних в международном частном праве» обратил внимание на то, что вопрос охраны прав несовершеннолетних на международном уровне - это крайне деликатный вопрос, вызывающий особое внимание разработчиков международных конвенций в течение многих лет. Самая первая конвенция в данной области была принята в еще 1902 г. (Гаагская конвенция об опеке над несовершеннолетними), однако она известна в мире и по сей день. Именно вопрос о сфере действия данной Конвенции оказался в центре дела «Болль», рассмотренного Международным Судом ООН в 1958 г. Данное дело выявило проблемы обеспечения охраны прав несовершеннолетнего, если страна места его жительства не является страной его гражданства. Дело «Болль» привело к возобновлению 
размышлений о защите несовершеннолетних и к увеличению числа международных договоров в данной области.

Особый интерес вызывают две важнейшие конвенции, ратифицированные как Россией, так и Францией: Гаагская конвенция о юрисдикции, применимом праве, признании, исполнении и сотрудничестве в отношении родительской ответственности и мер по защите детей (1996) и Гаагская конвенция о международно-правовых аспектах похищения детей (1980). Конвенция 1996 г. регулирует общие вопросы охраны прав несовершеннолетних, Конвенция 1980 г. затрагивает более специфические вопросы, касающиеся незаконного перемещения детей. Кроме того, необходимо обратить внимание, что в рамках ЕС существует отдельный нормативно-правовой акт - Регламент «Брюссель II bis» (Регламент ЕC № 2201/2003 о компетенции, признании, и исполнении судебных решений по семейным делам и о производстве, касающемся ответственности родителей в отношении общих детей супругов), регулирующий отношения в данной области на территории ЕС.

Замита детей. Вопрос охраны прав детей регулирует Гаагская конвенция 1996 г., действующая во Франции с 2011 г. и с 1 июня 2013 г. вступившая в силу в России. Таким образом, она является частью позитивного права обоих государств. Гаагская конвенция 1996 г. закрепляет два основополагающих принципа. Во-первых, основной коллизионной привязкой выступает право государства места жительства ребенка. Это означает, что применение такой коллизионной привязки, как закон гражданства ребенка, практически исключается. Гаагская конвенция 1996 г. завершила эволюцию правового регулирования в области защиты детей, начавшуюся уже достаточно давно: отныне считается, что наилучшим образом позаботиться об охране прав ребенка способны судьи по месту его жительства, а не судьи страны его гражданства.

Эти судьи будут применять их собственное право - в этом заключается второй основополагающий принцип Гаагской конвенции 1996 г. Так, Конвенция устанавливает тесную связь между компетентным судом и применимым правом. Ребенок, являющийся гражданином Франции, но проживающий на территории России и нуж- дающийся в применении к нему мер по защите его личности или имущества, будет защищаться российским судом в соответствии с положениями российского законодательства.

Конечно, существуют определенные изъятия из этих основополагающих принципов и особенности их применения, однако, именно эти два принципа лежат в основе Гаагской конвенции 1996 г.

Перемещение ребенка. К сожалению, при расторжении брака между гражданами двух разных государств часто случается так, что один из родителей забирает ребенка из страны, в которой последний имел постоянное место жительства, и привозит его в другую страну, где просит у компетентных органов изменения или отмены права другого родителя на общение с ребенком и участие в его воспитании. Подобные ситуации травмируют ребенка и уже создавали серьезные дипломатические проблемы между некоторыми странами.

По этой причине многими странами, в том числе Францией (1983) и Россией (2011), была подписана и ратифицирована Гаагская конвенция о международно-правовых аспектах похищения детей (1980), регулирующая этот специфический вопрос. В основе Конвенции 1980 г. также лежат два принципа. Первый из них может быть сформулирован следующим образом: если вывоз ребенка в другую страну был незаконным, суд страны, куда был перевезен ребенок, не имеет права принимать какие-либо решения о родительских правах в отношении данного ребенка. Второй принцип заключается в том, что судья страны, куда был привезен ребенок, обязан, напротив, предписать немедленно возвратить ребенка в страну, где он проживал до его перемещения. Для обеспечения такого возвращения было установлено административное сотрудничество через посредство центральных компетентных органов.

Из этих двух принципов также существует ряд исключений. Однако основополагающий характер и успех Гаагской конвенции 1980 г. основан на том, что незаконное перемещение ребенка признается недопустимым, и любые споры о детях должны рассматриваться судом по их месту жительства.

Обе Гаагские конвенции, дополненные в Европе Регламентом «Брюссель II bis», показывают, что в центре применения всех механизмов защиты несовершеннолетних находится 
суд постоянного места жительства ребенка. Основной целью конвенций и Регламента было физическое сближение компетентных органов и ребенка, нуждающегося в их вмешательстве. Представляется, что указанная цель была в полной мере достигнута.

МЧП в области семейных правоотношений и государства, не входящие в состав ЕC. Международное частное право в области семейных правоотношений находится в Европе в стадии кодификации. Большое число регламентов ЕС было принято практически по всем вопросам: развод, ответственность родителей, алиментные обязательства, наследование, режим имущества супругов. Все эти регламенты содержат нормы, касающиеся коллизий законов и коллизий юрисдикций, разрешают вопросы процессуального разграничения, определения применимого права и международного сотрудничества в данной области. Однако ввиду того, что МЧП имеет национальный характер, регламенты ЕС иногда с трудом сочетаются с другими источниками права, в особенности, если отношение связано с государствами, не являющимися членами ЕС (например, Россия).

Прежде всего, существует проблема, связанная с компетенцией ЕС. Формулировка ст. 65 Договора о Европейских сообществах (теперь ст. 81 ДФЕС) заставляла сомневаться не только в наличии компетенции Союза по принятию норм МЧП, но также и по вопросу о придании таким нормам универсального характера. Решение, принятое европейским законодателем и Европейским судом состояло в том, что Союз обладает широкой компетенцией. Коллизионные нормы, таким образом, в большинстве случаев имеют универсальное применение. Более того, Европейский суд в своем знаменитом заключении C-1/03 от 7 февраля 2006 г. подтвердил, что внешняя компетенция по вопросам МЧП действительно принадлежит Союзу, который единственный обладает правом заключать международные договоры в этой области. Данное решение может вызвать ряд серьезных дипломатических трудностей, как это показывает рассматриваемый в настоящее время запрос на заключение C-1/13 о присоединении государств, не являющихся членами ЕС, к Гаагским конвенциям, в частности, к Конвенции 1980 г. Однако остается принцип, который предполагает передачу ЕС как можно большей компетенции.

Помимо вопроса о компетенции ЕС возникает трудность с определением точного объема коллизионных норм. Наиболее простое решение, которому следуют все регламенты, состоит в принятии так называемых унифицированных коллизионных норм, т.е. таких, которые делают применимым и право государств-членов, и право третьего государства. Это решение явным образом одобряется и представляется единственно применимым. Любое другое решение могло бы привести к непреодолимым сложностям в разрешении конфликта между коллизионными нормами, указывающими в качестве применимого право государства-члена, и коллизионными нормами, указывающими на применение права третьего государства.

Однако данные решения должны быть приведены в соответствие с большим числом международных договоров, участниками которых являются государства-члены, и, в частности, с Гаагскими конвенциями. В этом отношении есть несколько возможных решений.

Наиболее классическое решение (малоприменимое в международном семейном праве), состоит в признании применимой более ранней конвенции. Примером такого решения, принятого во Франции, является недавнее предписание Министерства юстиции, касающееся гомосексуальных браков и предусматривающее отказ в применении определенных норм ФГК в отношении некоторых государств, с которыми Франция имеет двусторонние международные договоры (как, например, с Польшей). Франко-польский договор (1967) предусматривает, что правом, применимым по вопросам брака, является право страны гражданства. Франция решила, что применение новой нормы п. 2 ст. 202-2 ФГК теперь невозможно и, таким образом, заключение однополого брака между гражданином Польши и гражданином Франции не может иметь места. В любом случае, такое решение предполагает наличие специального двустороннего договора. Если же такового нет (как с Россией), то брак между двумя мужчинами (или двумя женщинами), проживающими во Франции, даже если они являются гражданами государств, в которых запрещены однополые браки, возможен. 
Другой, очень оригинальный, способ решения предложен в Регламенте об алиментных обязательствах, отсылающем по вопросу о коллизионных нормах к содержанию Гаагского протокола 2007 г. В данном случае имеет место достаточно эффективное делегирование законодательной обязанности.

Наибольшую трудность вызывает, без сомнения, определение норм о юрисдикционной компетенции. Способы решения в данном случае достаточно разнообразны, но в основном они состоят в попытке сближения (под видом взаимодействия) норм европейского права и норм национального права или посредством принятия субсидиарных норм европейского права. Особо острые дискуссии вызывает вопрос об исключительной компетенции ввиду его чрезвычайной важности, в частности, относительно компетенции, основанной на гражданстве. Представляется, что в будущем решением, например, по вопросам расторжения брака, может быть полная отмена условия о компетенции, основанной на гражданстве, если супруги имеют местожительство в Европе, и ее использование только, если местожительство супругов находится в третьем государстве. Распространение forum necessitas, которое встречается все чаще, представляется эффективным решением.

Наконец, остается вопрос о признании и свободном движении судебных решений. В рассматриваемой области с очевидностью необходимо наличие двух разных режимов в отношении государств-членов ЕС и третьих государств. Пример взаимодействия конвенций 1980 и 1996 гг. и регламента Брюссель II bis показывает, что попытка сосуществования специфического режима ЕС и международного сотрудничества вполне возможна.

Н.В. Ростовцева в своих докладах по теме «Защита несовершеннолетних в российском праве» проанализировала проблемы гарантий защиты имущественных прав несовершеннолетних в российском гражданском законодательстве ${ }^{5}$ и применения в России Гаагской конвенции о

\footnotetext{
${ }_{5}^{5}$ Подробнее о проблемах реализации имущественных прав несовершеннолетних см.: Ростовцева Н.B. О реализации несовершеннолетними имущественных прав // Хозяйство и право. 2013. № 10. С.106-117.
}

гражданско-правовых аспектах международного похищения детей (1980).

Несовершеннолетний является самостоятельным субъектом как личных, так и имущественных прав. Применительно к ребенку обычно принято говорить о его личных правах. Как международные акты, так и внутреннее законодательство (прежде всего семейное) уделяют основное внимание личности ребенка. При этом в российском гражданском законодательстве закреплен широкий спектр гарантий защиты $u м y$ щественных прав несовершеннолетних. Ребенок может быть собственником имущества, которое перешло к нему, например, в порядке наследования, в результате приватизации квартиры, по договору дарения и т.п.

В соответствии с нормами ГК РФ несовершеннолетние (не достигшие 18 лет) не наделены полной дееспособностью. Исключение составляют только несовершеннолетние, вступившие в брак до 18 лет, и эмансипированные. Учитывая то, что несовершеннолетние в силу своего возраста и психических особенностей не обладают достаточной зрелостью для самостоятельного распоряжения имуществом, ГК РФ устанавливает особые меры, направленные на защиту имущественных прав ребенка.

По общему правилу от имени малолетних (т.е. не достигших 14 лет) сделки совершают их родители, усыновители или опекуны (п. 1 ст. 28 ГК РФ). Исключение составляют ограниченный круг сделок, которые вправе совершать малолетние в возрасте от 6 до 14 лет (например, купить мороженое, канцелярские принадлежности, принять некрупный подарок). Несовершеннолетние в возрасте от 14 до 18 лет заключают сделки сами, но в случаях, предусмотренных законом, требуется получение письменного согласия родителей, усыновителей или попечителей (п. 1 ст. 26 ГК РФ). Таким образом, отсутствие полной дееспособности несовершеннолетних восполняется действиями их законных представителей.

В целях предотвращения возможных злоупотреблений со стороны законных представителей ГК РФ (ст. 37) устанавливает следующее ограничение: на совершение сделки, которая влечет уменьшение имущества несовершеннолетнего, или дачи согласия на совершение подобной сделки, требуется получить разрешение органа опеки 
и попечительства. Например, если 10-летнему ребенку принадлежит на праве собственности квартира, сделку продажи квартиры несовершеннолетнего может совершить один из родителей (либо усыновитель, либо опекун), но при условии получения согласия органа опеки и попечительства, который, в свою очередь, должен проверить, соответствует ли совершение подобной сделки интересам несовершеннолетнего.

Кроме того, ГК РФ устанавливает запрет на совершение сделок законным представителем с несовершеннолетним, за исключением передачи ребенку имущества в качестве дара. Например, не может быть совершена сделка дарения имущества несовершеннолетнего в пользу отца ребенка. Однако отец подарить имущество ребенку вправе.

Родители как законные представители несовершеннолетних могут быть сами несовершеннолетними. В соответствии со ст. 62 Семейного кодекса РФ несовершеннолетние родители, не вступившие в брак, по достижении 16 лет вправе самостоятельно осуществлять родительские права. Между тем по нормам ГК РФ такие родители не являются полностью дееспособными. Возникает интересная ситуация: распоряжаться собственным имуществом родитель по общему правилу не может без согласия своих законных представителей, а совершать сделки от имени своего ребенка 16-летний родитель вправе.

Следует отметить, что разрешение органов опеки и попечительства на совершение сделок по отчуждению имущества несовершеннолетних предусмотрено лишь в тех случаях, когда несовершеннолетний является собственником имущества.

Представим теперь ситуацию, когда ребенок является пользователем, например, жилого помещения, не являясь при этом собственником. Предположим, несовершеннолетний ребенок проживает в квартире, принадлежащей на праве собственности отцу ребенка. Родители развелись. Отец ребенка хочет продать квартиру. Требуется ли в данном случае получение согласия органа опеки и попечительства на совершение подобной сделки? В соответствии со ст. 292 ГК РФ (в ред. от 1 января 2005 г.) такое разрешение не требуется. Более того, установлено, что переход права собственности на жилой дом или квартиру к другому лицу является основанием для прекращения права пользования жилым помещением членами семьи прежнего собственника. Другими словами, отец вправе продать квартиру и выселить ребенка из жилого помещения. Статья 292 ГК РФ в прежней редакции закрепляла прямо противоположное правило. Представляется, что действующие нормы ст. 292 ГК РФ в меньшей степени отвечают интересам несовершеннолетних.

Особым способом приобретения несовершеннолетним права собственности на жилое помещение является приватизация - бесплатная передача в собственность российских граждан на добровольной основе занимаемых ими жилых помещений в государственном и муниципальном жилищном фонде. Закон РФ «О приватизации жилищного фонда в Российской Федерации» предусматривает специальные положения, обеспечивающие гарантии защиты прав несовершеннолетних. Наиболее значимые положения данного Закона:

Несовершеннолетние, в отличие от совершеннолетних, могут участвовать в приватизации 2 раза (первый раз - до достижения возраста 18 лет, второй раз - после достижения 18 лет).

Участие в приватизации несовершеннолетних пользователей жилого помещения является обязательным. Таким образом, если, например, в квартире проживают родители с несовершеннолетними детьми, при приватизации квартиры несовершеннолетние должны быть включены в число собственников жилого помещения. Нарушение этого положения может привести к признанию приватизации недействительной.

Можно привести конкретный пример из практики. В 1992 г. была оформлена приватизация квартиры. Однако несовершеннолетний, проживавший в жилом помещении, при оформлении приватизации не был включен в число собственников. На момент приватизации квартиры ребенку было 4 года. В 2011 г. после смерти одного из собственников квартиры ребенок, ставший к этому моменту совершеннолетним, узнал, что не был включен в число собственников жилого помещения. В 2012 г. он обратился за защитой своих прав в суд с требованием признать договор передачи жилого помещения недействительным и признать за ним право собственности на $1 / 4$ доли в квартире. Ответчик ссылался на то, что срок исковой давности пропущен. Суд посчитал, что срок исковой давности не истек, так как этот 
срок начинает течь со дня, когда лицо узнало или должно было узнать о нарушении своего права (ст. 200 ГК РФ). Истец узнал о том, что его права были нарушены в 2011 г., обратился в суд в 2012 г. Договор передачи квартиры в собственность был признан недействительным как совершенный с нарушением права несовершеннолетнего на участие в приватизации (Определение Пермского краевого суда от 20.02.2013 по делу № 33-1681).

Особого внимания заслуживает вопрос о гарантиях защиты имущественных прав несовершеннолетних в наследственных правоотношениях. ГК РФ устанавливает особые положения:

1. Дети (в том числе несовершеннолетние) являются наследниками первой очереди наряду с супругом и родителями наследодателя. Кроме того, к наследованию могут призываться и граждане, зачатые при жизни наследодателя и родившиеся живыми после открытия наследства.

2. Внебрачные дети имеют те же наследственные права, что и законнорожденные. Кстати, во Франции до вступления в силу Закона от 3 декабря 2001 г. № 2001-1135 положение внебрачных детей было хуже по сравнению с законнорожденными. Так, при наследовании по закону внебрачные дети могли рассчитывать только на половину доли, которая им причиталась, если бы они являлись законнорожденными детьми.

3. Согласно ГК РФ несовершеннолетние, даже не связанные кровным родством с наследодателем, могут в отдельных случаях претендовать на наследство. Так, пасынки и падчерицы (т.е. неусыновленные наследодателем дети его супруга) призываются к наследованию по закону в качестве наследников 7 очереди.

4. Если совершено завещание, несовершеннолетние (в том числе, полностью дееспособные в результате вступления в брак или эмансипации) могут рассчитывать на обязательную долю в наследстве. В соответствии с ГК РФ обязательная доля составляет не менее половины законной доли.

5. Внуки наследодателя и их потомки, племянники и племянницы, двоюродные братья и сестры (в том числе несовершеннолетние) могут наследовать по праву представления, как бы представляя (замещая) своего роди- теля, который умер ранее наследодателя. При этом по российскому законодательству потомки недостойного наследника по праву представления наследовать не могут (т.е. дети отвечают за действия своих родителей), а по французскому законодательству - могут. Подход французского законодателя по отношению к детям в этом вопросе представляется более гуманным.

В настоящее время тема международного похищения детей является для России очень актуальной. По данным Министерства образования и науки, в Российской Федерации ежегодно регистрируется 60-70 тыс. браков с иностранцами. В случае расторжения такого брака возникает главный вопрос: с кем останется ребенок, где он будет жить? Если родители ребенка, граждане разных государств, не могут мирно решить этот вопрос, один из родителей иногда похищает ребенка и увозит в свою страну.

Таких историй много. Одно из дел вызвало особый резонанс в России и Франции и к разрешению семейных проблем вынуждены были подключиться даже политики. Не обошлось без участия Министерства иностранных дел России, представителей Общественной палаты Российской Федерации, общественных деятелей. Мать, гражданка России, Ирина Беленькая, и отец-француз, Жан-Мишель Андре, не смогли договориться об определении места жительства дочери. Их дочь Лиза (Элиза) родилась в Москве в ноябре 2005 г. Семья жила во Франции. В 2007 г. отношения между супругами разладились. В ноябре 2007 г. Жан-Мишель обратился в суд с иском о расторжении брака. Он также просил суд запретить выезд дочери за пределы Франции без согласия обоих родителей. Суд удовлетворил просьбу отца, издав соответствующее постановление. Однако в декабре 2007 г. Ирина тайно вывезла ребенка в Россию.

Французский суд установил факт нарушения Ириной постановления суда о незаконном вывозе ребенка и определил, что решение вопросов воспитания ребенка предоставлено отцу, с которым и должна жить девочка. Жан-Мишель приехал в Россию и попытался уговорить Ирину о возвращении ребенка во Францию, однако получил от нее отказ. Российские правоохранительные органы также отказали Жану-Мишелю в исполнении 
решения французского суда. По российскому уголовному закону похищение ребенка не признается таковым, если ребенка увез один из родителей без применения насилия к ребенку.

Дело приняло широкую огласку со стороны средств массовой информации. Российские власти выступили в защиту интересов Ирины. Французский суд встал на сторону прав отца ребенка. Юридической возможности урегулировать подобную ситуацию не было ввиду отсутствия международного договора между двумя странами о признании и исполнении иностранных решений на территории обоих государств. Российский суд не был связан обязательством по исполнению решения французского суда. Россия не обязана была обеспечить возврат ребенка во Францию, даже если родитель незаконно вывез ребенка в Россию.

Эта история закончилась тем, что в сентябре 2008 г. Жан-Мишель забрал ребенка во время прогулки девочки с няней и увез ее во Францию. Ирина в марте 2009 г. второй раз организовала похищение ребенка. Ирину объявили в международный розыск, и она была арестована на венгерской границе. Элиза была передана приехавшему в Венгрию отцу. В октябре 2012 г. исправительный суд города Тараскон приговорил Ирину за похищение ребенка к двум годам тюремного заключения условно, т.е. наказание оказалось достаточно гуманным со стороны французского правосудия.

Такой трагичной для ребенка истории с тремя похищениями могло бы и не быть, если бы на момент развития описанных событий Россия являлась участницей Гаагской конвенции о гражданско-правовых аспектах международного похищения детей 1980 г. (далее - Конвенция 1980 г.). Конвенция была заключена в Гааге 25 октября 1980 г. и вступила в силу 1 декабря 1983 г. По состоянию на 1 октября 2013 г. число стран-участниц составило 90. Россия присоединилась к Конвенции в соответствии с Федеральным законом от 31 мая 2011 г. № 102Ф3. В Российской Федерации Конвенция 1980 г. действует с 1 октября 2011г.

Основная идея Конвенции 1980 г. заключается в том, что любой ребенок, незаконно вывезенный из страны обычного проживания (или удерживаемый вне ее), должен быть незамедлительно возвращен домой. Правовой механизм, заложенный в Конвенции, позволяет защитить детей от вредных последствий трансграничного похищения и незаконного удержания. Гаагская конвенция регулирует отношения в сфере частного права. Понятие «похищение», применяемое в Конвенции, имеет другое, отличное от уголовного права, значение. Случаи похищения детей, содержащие признаки преступления, к предмету правового регулирования Конвенции не относятся. Согласно Конвенции 1980 г. действия родителя будут рассматриваться как международное похищение при наличии следующих условий:

1. ребенок постоянно проживал в России (или другой стране-участнице Конвенции 1980 г.); при этом гражданство ребенка и родителей не имеет значения и не учитывается при вынесении решения о возвращении;

2. ребенок перемещен или удерживается за границей с нарушением прав опеки, причем эти права эффективно осуществлялись до его перемещения;

3. ребенок не достиг 16-летнего возраста.

В соответствии со ст. 5 Конвенции «права опеки» включают права, относящиеся к заботе о личности ребенка, в частности, право определять место жительства ребенка. В случае раздельного проживания родителей может быть установлена как единоличная, так и совместная опека. Права опеки могут возникнуть, в частности, в соответствии с законом либо на основании судебного или административного решения, либо на основании соглашения, влекущего юридические последствия по законодательству государства (ст. 3). В Конвенции используется и понятие «право доступа». Оно включает право взять ребенка на ограниченный период времени в место, иное, чем место его постоянного проживания (ст. 5).

Ключевым понятием в Конвенции 1980 г. является понятие обычного места жительства ребенка (résidence habituelle). Компетентные opганы именно страны обычного места жительства ребенка могут применить правовые механизмы, направленные на защиту прав детей. Целью Конвенции 1980 г. является физическое сближение компетентных органов и ребенка.

Конвенция 1980 г. устанавливает процедуру, обеспечивающую возвращение незаконно перемещенного ребенка. В соответствии со ст. 6 Договаривающееся государство назначает Центральный орган, который принимает меры 
для обнаружения местонахождения ребенка и обеспечения скорейшего возвращения ребенка в страну его обычного проживания, оказывает и другие виды содействия, предусмотренные ст. 7 Конвенции. Согласно Постановлению Правительства РФ от 22 декабря 2011 г. № 1097 Центральным органом в России определено Министерство образования и науки РФ. В большинстве стран, присоединившихся к Конвенции (в том числе, во Франции), Центральным органом является Министерство юстиции.

Конвенция 1980 г. содержит ряд ограничений на возвращение детей в страну его обычного проживания. Так, в удовлетворении заявления о возвращении ребенка суд может отказать, например, в случае, когда с момента похищения прошло более одного года, и ребенок адаптировался к новой среде (ст. 12). Другие исключительные обстоятельства предусмотрены в ст. 13 и 20 Конвенции.

Присоединение России к Конвенции 1980 г. можно рассматривать, безусловно, как положительный момент. Конвенция является действенной мерой, которая позволит сократить случаи незаконного перемещения или удержания детей и поможет цивилизованно разрешать семейные конфликты. Кроме того, опыт применения Конвенции в других государствах свидетельствует о том, что она оказывает огромное превентивное воздействие.

Однако эффективному применению Конвенции 1980 г. в России могут воспрепятствовать следующие обстоятельства.

1. Имеется несоответствие отдельных положений российского законодательства правилам Конвенциии 1980 г.

Например, согласно положениям Конвенции 1980 г. перемещение ребенка одним родителем без согласия другого родителя может рассматриваться как незаконное. Между тем, подобные действия с позиции российского законодательства признаются правомерными. Так, в соответствии со ст. 20 Федерального закона от 15 августа 1996 г. «О порядке выезда из Российской Федерации и въезда в Российскую Федерацию» несовершеннолетний вправе выезжать из Российской Федерации с одним из родителей. Согласие другого родителя не требуется.

Понятие родительской опеки, применяемое в Конвенции 1980 г., не имеет ничего общего с понятием опеки, которым оперирует российское законодательство. По российскому праву опека устанавливается над детьми, не достигшими возраста 14 лет, если они остались без попечения родителей (например, в случае смерти родителей, их болезни, по иным причинам). В соответствии со ст. 31 ГК РФ опека устанавливается для защиты прав и интересов ребенка, а также в целях его воспитания. Назначенные органами опеки и попечительства граждане (опекуны) являются законными представителями подопечных и совершают от их имени и в их интересах все юридически значимые действия (ст. 2 Федерального закона от 24 апреля 2008 г. № 48-Ф3 «Об опеке и попечительстве»).

Неизвестно российскому законодательству и «право доступа». Некоторые ученые полагают, что аналогом права доступа в семейном праве России является право родителя, проживающего отдельно от ребенка, на общение с ним и участие в его воспитании (это право закреплено в п. 1 ст. 66 Семейного кодекса РФ). Кроме того, в ст. 4 Конвенции 1980 г. установлено, что ее применение прекращается, когда ребенок достигает возраста 16 лет. Однако согласно Конвенции ООН о правах ребенка 1989 г. и Семейному кодексу РФ ребенком признается лицо, не достигшее возраста 18 лет.

Таким образом, для эффективного применения Конвенции 1980 г. требуется приведение норм внутреннего законодательства в соответствие с ее положениями.

2. В Конвенциии 1980 г. не раскрывается понятие «обычное место жительства ребенка» (résidence habituelle). Каким образом определить обычное место жительства ребенка, если он перемещается из одного государства в другое или ребенок зарегистрирован в одном государстве, а фактически проживает в другом? В Конвенции не определены даже примерные ориентиры для идентификации данного юридического факта, что может вызвать сложности на практике.

3. Конвенция 1980 2. не подлежит применению, если государство, в котором находится ребенок, не признало Россию в качестве участницы Конвениии. Например, если ребенка похитили из России и увезли в Германию, применить Конвенцию 1980 г. будет невозможно (несмотря на то, что Германия ратифицировала ее в 
1990 г.), потому что Германия не подтвердила признание России как участницы Конвенции. По состоянию на 1 октября 2013 г. только 30 из 90 стран признали Россию как участницу Конвенции (Франция, Испания, Финляндия, Греция, Израиль, Аргентина, Бразилия, Армения, Украина, Узбекистан и др.).

Российское государство уже предпринимает определенные шаги для разрешения проблем, связанных с применением Конвенции 1980 г. Так, Министерство образования и науки РФ подготовило проект закона «О внесении изменений в отдельные законодательные акты Российской Федерации в связи с присоединением Российской Федерации к Конвенции».

Применению Конвенции о гражданско-правовых аспектах международного похищения детей 1980 г. будут способствовать дополнительные положения Гаагской Конвенции от 19 октября 1996 г. о юрисдикции, применимом праве, признании, исполнении и сотрудничестве в отношении родительской ответственности и мер по защите детей. Указанная Конвенция вступила в силу для России с 1 июня 2013 года. В сентябре этого года Московский городской суд впервые вынес решение, опираясь на положения данной Конвенции. Мосгорсуд удовлетворил иск о признании и принудительном исполнении на территории России решения иностранного суда: обязал гражданина России (бывшего мужа гражданки США Рэйчел Нойштадт) вернуть вывезенных в Россию детей.

По третьему направлению исследования «Международный коммерческий арбитраж и альтернативные методы разрешения международных споров» с докладами выступили:

Паскаль де Варей-Соммьер в своих докладах по теме «Публичный порядок и исполнение иностранных арбитражных решений во Франции» ${ }^{6}$ обратил внимание на то, что Франция (как и Россия) участвует в НьюЙоркской конвенции о признании и приведении в исполнение иностранных арбитражных решений

\footnotetext{
${ }^{6}$ Идеи, данные и результаты исследования, проведенного при подготовке настоящего доклада, будут развиты и углублены автором в научной статье «La sentence arbitrale étrangère contraire à une loi d'ordre public du for», планируемой к опубликованию в одном из французских журналов.
}

(1958). Следовательно, именно положения данной Конвенции должны применяться во Франции всякий раз, когда на ее территории испрашивается приведение в исполнение иностранного арбитражного решения, вынесенного в России или другой стране (ст. 1 Нью-Йоркской конвенции).

При этом, согласно ч. 1 ст. 7 Конвенции, заинтересованная сторона, испрашивающая приведение в исполнение арбитражного решения во Франции, сохраняет за собой право воспользоваться положениями французского законодательства. Поскольку таковые предусматривают более благоприятные условия признания и приведения в исполнение иностранных арбитражных решений, нежели положения Нью-Йоркской конвенции, лицо, в пользу которого вынесено решение, как правило, опирается именно на нормы французского права, испрашивая исполнение этого решения во Франции. Соответствующие положения французского права содержатся в ГПК Франции (ст. 1516) и в Кодексе гражданского исполнительного производства Франции (ст. L. 111-2, L. 111-3 $\left(2^{\circ}\right)$ ). Декретом № 2011-48 от 13 января 2011 г. в эти кодексы были внесены поправки.

Во Франции иностранное арбитражное решение подлежит исполнению только после выдачи экзекватуры. На первом этапе процедуры принятия решения о выдаче экзекватуры суд выдает экзекватуру только при условии, что приведение иностранного арбитражного решения в исполнение «не противоречит явным образом международному публичному порядку» (ст. 1514 ГПК). Условие, сформулированное таким образом, соответствует условию, содержащемуся в ч. 2 пп. $\mathrm{b}$ ст. V Конвенции, и уточняет его. Государство, на территории которого испрашивается приведение в исполнение арбитражного решения, вправе в таком исполнении отказать, если арбитражное решение «противоречит публичному порядку этого Государства».

Определение содержания публичного порядка представляет собой нелегкую задачу, однако могут быть определены некоторые общие принципы - «система принципов и ценностей, составляющая французский публичный порядок, не может не признаваться даже в международных делах». Недавняя судебная практика внесла два важных уточнения по вопросу о содержании международного материального публичного порядка, заметив 
при этом, что существует также процессуальный международный публичный порядок.

Анализируя французскую судебную практику по вопросу материального публичного порядка, можно сделать два вывода.

1. Противоречие иностранного арбитражного решения франиузскому внутреннему публичному порядку недостаточно для обоснования отказа в выдаче экзекватуры. Мотивом отказа в выдаче экзекватуры, предусмотренным в ст. 1520 ГПК Франции, является противоречие «международному публичному порядку», а не внутреннему публичному порядку. Французское право строго разделяет эти два вида публичного порядка; в этом отношении оно более определенно по сравнению с Нью-Йоркской конвенцией, которая упоминает только противоречие «публичному порядку», не указывая специально, что в данном случае речь идет о понятии, отличном от понятия, используемого во внутреннем праве. Однако разница между этими двумя понятиями в области международных частных правоотношений чрезвычайно существенна. Арбитражное решение, вынесенное за границей (как и иностранное судебное решение), которое может оказаться противоречащим внутреннему публичному порядку государства, в котором испрашивается его исполнение, ipso facto не противоречит международному публичному порядку данного государства. Таким образом, решение может быть исполнено при условии, что противоречие международному публичному порядку в дополнение к противоречию внутреннему публичному порядку не установлено.

Подобное разграничение международного и внутреннего публичного порядка встречается не только в вопросах приведения в исполнение иностранных арбитражных решений. Оно используется, помимо прочего, в смежной области признания и приведения в исполнение во Франции иностранных судебных решений. В недавнем решении Первой палаты по гражданским делам Кассационного суда от 8 июля 2010 г. № 08-21.740 уточняется, что международный публичный порядок состоит из «фундаментальных принципов французского права». Из этой категории исключаются положения внутреннего публичного порядка, которые не отвечают качеству основополагающих принципов фран- цузского права. В итоге можно сделать вывод, что простое нарушение иностранным судебным решением нормы внутреннего публичного порядка недостаточно для того, чтобы в наших глазах сделать решение не соответствующим публичному порядку, если соответствующая норма не относится к категории «основополагающих принципов французского права».

В решении Первой палаты по гражданским делам Кассационного Суда от 30 января 2013 г. № 11-10.588 о признании во Франции российского судебного решения указывалось, что ст. L.341-1 Потребительского кодекса Франции (норма внутреннего публичного порядка) «содержит норму, неприменение которой иностранным судьей не противоречит французской концепции международного публичного порядка».

Принято считать, что фильтр публичного порядка, через который должно пройти арбитражное решение (как и решение государственного суда), чтобы быть исполненным во Франции, был бы слишком жестким, если бы он относился к французскому внутреннему публичному порядку без ограничений. Причины такой точки зрения варьируются в зависимости от того, было ли решение вынесено с применением французского права или нет.

Если арбитражное решение вынесено с применением иностранного материального права, не подлежащего применению в соответствии с французской коллизионной нормой, было бы противоречием требовать от арбитражного решения полного соблюдения французского внутреннего публичного порядка. Внутренний публичный порядок французского права может полностью применяться только в том случае, когда отношение наиболее тесно связано с правом Францией.

Если арбитражное решение вынесено с применением компетентного французского права, то осуществление контроля за этим решением с точки зрения его соответствия французскому внутреннему публичному порядку означало бы пересмотр его по существу. По общему правилу, пересмотр иностранного решения по существу не признается, поскольку представляет собой посягательство на обязательную силу судебного постановления, которой обычно наделяется арбитражное решение и которая составляет основной интерес для сторон. 
2. Простое нарушение арбитражным решением императивных норм, действуюших во Франции, недостаточно для признания противоречия решения международному публичному порядку. На сегодняшний момент в доктрине остается спорным вопрос, являются ли императивные нормы страны суда частью его международного публичного порядка. Искушение ответить на этот вопрос утвердительно является достаточно сильным, так как императивные нормы часто называются «международно-императивными нормами», «нормами непосредственного действия» или «нормами международного публичного порядка». До настоящего момента Кассационный Суд устоял перед этим искушением. Действительно, если бы французские императивные нормы были составной частью французского международного публичного порядка, простое нарушение арбитром французской императивной нормы означало бы нарушение международного публичного порядка. Однако такое решение было отклонено регулярной судебной практикой Кассационного Суда начала XXI века. Отказ в выдаче экзекватуры на основании несоответствия арбитражного решения публичному порядку может иметь место лишь в том случае, если нарушение национальной императивной нормы или императивной нормы международного права носит «очевидный, реальный и конкретный характер».

В деле SNF c. Суtес оценка арбитром последствий признания недействительным договора, противоречащего европейскому конкурентному праву, не была поставлена под сомнение французским судом на основании предполагаемого противоречия арбитражного решения международному публичному порядку, поскольку это предполагаемое противоречие, если даже предположить, что оно было установлено, в любом случае не представляло бы собой очевидное, реальное и конкретное нарушение норм европейского конкурентного права.

Указанная позиция Кассационного Суда вызывает многочисленные дискуссии среди французских ученых. Некоторые из них положительно относятся к «принципу окончательности арбитражного решения», другие считают, что однозначное и бездумное следование этому принципу может нарушать международный публичный порядок и не совместимо с требованиями норм права ЕС, особенно если они носят императивный характер. Однако можно привести аргументы в пользу того, что французская судебная практика является вполне оправданной и основанной на разумных доводах.

В практике Кассационного Суда очевидно прибавление дополнительных условий, которые должны быть выполнены при нарушении публичного порядка. Естественно, создается впечатление, что Кассационный Суд указывает нарушение международного публичного порядка наказывается лишь в случае, когда нарушение носит очевидный, реальный и конкретный характер. Таким образом, для нарушения международного публичного порядка необходимо сочетание всех этих трех элементов. Однако решение Кассационного Суда можно интерпретировать и по-иному: при наличии императивного закона, примененного арбитром, только лишь очевидное, реальное и конкретное нарушение относится к нарушению публичного порядка. Иначе говоря, это не нарушение международного публичного порядка должно быть конкретным, реальным и очевидным, а нарушение императивных норм должно соответствовать трем этим критериям, чтобы иметь последствием простое нарушение международного публичного порядка.

Противоречий французской судебной практики по делу SNF против Cytec практике Европейского Суда в Люксембурге не установлено. Обычно цитируются также два европейских судебных решения: решение по делу Eco Swiss и Claro; представляется, что французская судебная практика вполне совместима и с этими двумя решениями.

Решение по делу Eco Swiss требует, чтобы судебный орган государства-члена аннулировал арбитражное решение, не соответствующее европейским императивным нормам (например, нормам европейского права в области конкуренции). Между тем французское право не требует от судьи, решающего вопрос об экзекватуре или осуществляющего контроль за действительностью арбитражного решения, чтобы он признавал иск об аннулировании арбитражного решения, основываясь на неприменении национальных норм публичного порядка. Для того, чтобы суд удовлетворил иск об аннулировании арбитражного решения, требуется, чтобы требование было 
основано на неприменении международного публичного порядка, в важной степени отличающегося от норм внутреннего публичного порядка.

Решение по делу Claro относится не к вопросу контроля соответствия судебного решения публичному порядку, а к вопросу контроля действительности арбитражного соглашения, когда такое соглашение было заключено в рамках недействительного договора. Проблема в данном случае заключается не в публичном порядке, а в полномочиях арбитра. Отсутствие у арбитра соответствующих полномочий, являясь условием действительности арбитражного решения, отличается от условия соответствия публичному порядку.

Критика судебной практики Кассационного Суда Франции представляется необоснованной. В защиту этой практики говорит «удобство» получаемого результата: по вопросам, регулируемым императивными нормами, появляется возможность избежать как пересмотра арбитражного решения по существу на стадии экзекватуры, так и оспаривания силы судебного решения, придаваемого арбитражному решению, на которое стороны законно рассчитывают с момента, когда спор становится арбитрабельным.

Понятно, почему контроль соответствия арбитражного решения императивным нормам, является проблематичным: он ставит под сомнение силу арбитражного решения, которая составляет основной интерес, имеющийся у сторон. Понятно, почему французский судья неохотно признает такой контроль: соблюдение арбитром материальной императивной нормы не производится с целью лишить арбитражное решение его судебной силы. В этом и заключается причина отказа судебной практики признавать простое нарушение французских императивных норм в иностранном арбитражном решении в качестве посягательства на публичный порядок.

Н.Ю. Ерпылева в своем докладе «Публичный порядок как основание для отказа в признании и приведении в исполнение иностранных арбитражных решений» отметила, что наиболее важным вопросом международного коммерческого арбитража является вопрос о признании и приведении в исполнение арбитражного решения, вынесенного на территории государства, отличного от того, где испрашивается его признание и исполнение. От последнего, в конечном счете, зависит эффективность всего арбитражного разбирательства и справедливое удовлетворение материальных требований сторон. В международном процессуальном праве признание и исполнение иностранного арбитражного решения возможно по двум основаниям - в силу прямого указания внутригосударственного права и в силу международного договора. Оба эти основания имеют место в России, так как в настоящее время в России применяются нормы Закона РФ «О международном коммерческом арбитраже» от 07 июля 1993 г. (с последующими изменениями), а также нормы Нью-Йоркской конвенции ООН 1958 г. о признании и приведении в исполнение иностранных арбитражных решений, носящей универсальный характер и объединяющей в числе участников 149 государств (далее - НьюЙоркская конвенция).

Основы международного режима признания и исполнения иностранных арбитражных решений были заложены именно Нью-Йоркской конвенцией. Процедура признания и приведения в исполнении иностранного арбитражного решения в России регулируется нормами Арбитражного процессуального кодекса РФ от 24 июля 2002 г. (с последующими изменениями) (Глава 31 «Производство по делам о признании и приведении в исполнение решений иностранных судов и иностранных арбитражных решений») (далее - АПК РФ).

Согласно п. 2(b) ст. V Нью-Йоркской конвенции в признании и приведении в исполнение арбитражного решения может быть отказано, если компетентный орган страны, в которой испрашивается признание и приведение в исполнение, найдет, что признание и приведение в исполнение этого решения противоречит публичному порядку этой страны. Согласно п. 2 ст. 244 АПК РФ арбитражный суд отказывает в признании и приведении в исполнение полностью или в части иностранного арбитражного решения, а также в выдаче исполнительного листа на принудительное исполнение решения международного коммерческого арбитража в том случае, когда исполнение иностранного арбитражного решения противоречило бы публичному порядку России. Высший арбитражный суд РФ на основании рассмотренных арбитражными судами дел сформулировал свои рекомендации в Информационном 
письме № 156 «Обзор практики рассмотрения арбитражными судами дел о применении оговорки о публичном порядке как основания отказа в признании и приведении в исполнение иностранных судебных и арбитражных решений» от 26 февраля 2013 г. (далее - Обзор). Основные позиции ВАС РФ по данному вопросу сводятся к следующему.

1) В Обзоре сформулировано определение понятия «публичный порядок», под которым следует понимать фундаментальные правовые начала (принципы), которые обладают высшей императивностью, универсальностью, особой общественной и публичной значимостью, составляют основу построения экономической, политической, правовой системы государства. К таким началам, в частности, относится запрет на совершение действий, прямо запрещенных сверхимперативными нормами законодательства России (ст. 1192 ГК РФ), если этими действиями наносится ущерб суверенитету или безопасности государства, затрагиваются интересы больших социальных групп, нарушаются конституционные права и свободы частных лиц. Арбитражный суд отказывает в признании и приведении в исполнение иностранных арбитражных решений и по собственной инициативе, а не только по ходатайству взыскателя как заинтересованной стороны. При этом Сторона, заявляющая о противоречии признания и приведения в исполнение иностранного арбитражного решения публичному порядку России, должна обосновать наличие такого противоречия. В свою очередь, оценка арбитражным судом последствий исполнения иностранного арбитражного решения на предмет нарушения публичного порядка России не должна вести к его пересмотру по существу (п. 1-3 Обзора).

2) Арбитражный суд применяет оговорку о публичном порядке как основание для отказа в признании и приведении в исполнение иностранных арбитражных решений в исключительных случаях, не подменяя специальных оснований для отказа в таком признании и приведении в исполнение, предусмотренных международными договорами РФ и нормами АПК РФ. Так, нарушение порядка извещения стороны, против которой принято решение, о времени и месте рассмотрения дела, повлекшее невозможность представления ею в суд своих объяснений, является самостоя- тельным основанием отказа в принудительном исполнении арбитражного решения. Согласно п. 1(b) ст. V Нью-Йоркской конвенции в признании и приведении в исполнение арбитражного решения может быть отказано по просьбе той стороны, против которой оно направлено, если эта сторона представит компетентной власти по месту, где испрашивается признание и приведение в исполнение, доказательства того, что она не была должным образом уведомлена о назначении арбитра или об арбитражном разбирательстве либо по другим причинам не могла представить свои объяснения. Таким образом, при наличии специального основания для отказа в признании и исполнении иностранного арбитражного решения необходимость задействования механизма оговорки о публичном порядке ввиду ее экстраординарного характера отсутствует (п. 4 Обзора).

3) Признание и приведение в исполнение иностранного судебного или арбитражного решения не может нарушать публичный порядок России на том лишь основании, что в российском праве отсутствуют нормы, аналогичные нормам примененного иностранного права. В частности, законодательство России не предусматривает такие институты обязательственного права, как гарантии и заверения, заранее оцененные убытки. К нарушению публичного порядка России может привести не отсутствие в российском праве норм, аналогичных нормам иностранного права, а противоречие последних основополагающим принципам российского права, в частности, принципу компенсационной природы договорной ответственности. Таким образом, признание и приведение в исполнение иностранных арбитражных решений, предусматривающих взыскание заранее установленных в заключенных между контрагентами договорах убытков, противоречит публичному порядку России, в частности, при наличии следующих условий: если размер таких убытков настолько аномально высок, что многократно превышает тот их размер, который стороны могли разумно предвидеть при заключении договора; если при согласовании размера таких убытков имелись очевидные признаки злоупотребления свободой договора (в форме эксплуатации слабых переговорных возможностей должника, нарушения публичных интересов и интересов третьих лиц и др.) (п. 5-6 Обзора). 
4) Арбитражный суд признает иностранное арбитражное решение соответствующим публичному порядку России, если установит, что процедура арбитражного разбирательства обеспечивала соблюдение принщипа независимости и беспристрастности арбитров. С одной стороны, арбитражные регламенты налагают на арбитра обязанность при обращении к нему с предложением выступать арбитром, а также в последующем с момента его назначения и в течение всего арбитражного разбирательства (если он не уведомил стороны об этих обстоятельствах ранее) сообщать без промедления сторонам о любых обстоятельствах, которые могут вызвать обоснованные сомнения в его беспристрастности или независимости. С другой стороны, после раскрытия арбитром обстоятельств и фактов, которые могут вызывать обоснованные сомнения в отношении его беспристрастности и независимости, любая сторона вправе заявить об отводе такого арбитра. Если подобных заявлений не последовало, это означает отказ стороны от права на заявление о любом потенциальном конфликте интересов арбитра на основании таких обстоятельств и фактов (принщип отказа от права на возражение). Таким образом, соблюдение принципа независимости и беспристрастности арбитров, а также принципа отказа от права на возражение свидетельствует о соответствии иностранного арбитражного решения публичному порядку России (п. 11 Обзора).

5) Арбитражный суд должен отказать в удовлетворении заявления о признании и приведении в исполнение иностранного арбитражного решения как нарушающего публичный порядок России, если такое решение вынесено арбитром, который в силу своего должностного статуса и полномочий был способен оказывать влияние на действия одной из сторон (ситуация конфликта интересов). В частности, Руководящие принципы Международной ассоциации юристов относительно конфликта интересов в международном арбитраже 2004 г. включили тот факт, что арбитр является менеджером, директором или членом наблюдательного совета одной из сторон арбитражного разбирательства или обладает схожими полномочиями, позволяющими влиять на действия одной из сторон, в так называемый Красный перечень обстоятельств, которые безусловно свидетельствуют о конфликте интересов.
Фундаментальные принципы независимости и беспристрастности арбитров при рассмотрении споров входят в основу процессуального международного публичного порядка и поэтому подлежат безусловной защите. Данные процессуальные стандарты составляют основу и внутреннего публичного порядка России, поэтому могут служить причиной отказа в признании и приведении в исполнение иностранного арбитражного решения.

Каролин Кляйнер в своих докладах по теме «Французские суды и международный коммерческий арбитраж» уделила особое внимание влиянию финансового кризиса на выбор способа разрешения международных споров.

Французское право создает благоприятные условия для развития международного коммерческого арбитража, о чем свидетельствует проведенная недавно реформа, базовым элементом которой принято считать Декрет от 13 января 2011 г. Этот Декрет внес изменения в положения ГПК Франции, регулирующие осуществление правосудия французскими и международными арбитражными судами. Необходимо упомянуть, что начало подобного поощрения развития международного коммерческого арбитража было положено практикой Первой Палаты по гражданским делам Кассационного Суда, которая затем была закреплена в двух декретах, принятых в мае 1981 г. Первая Палата по гражданским делам впоследствии достаточно часто ссылалась на эти декреты с тем, чтобы превратить французское право в «плодородную» почву для развития арбитража.

Создание благоприятных условий для развития международного коммерческого арбитража выражается на сегодняшний день, во-первых, в ограничении французскими судьями своей компетенции при наличии действительного и исполнимого арбитражного соглашения, во-вторых, в контроле, осуществляемом в случае подачи заявления об отмене арбитражного решения или в случае рассмотрения заявления о признании и приведении в исполнение арбитражного решения.

1. Ограничение компетенции франиузского суда при наличии арбитражного соглашения. Большинство стран придерживается принципа компетенции-компетенции в его положительном аспекте, который предусматривает, что арбитраж 
наделен соответствующими полномочиями относительно решения вопросов собственной компетенции. В законодательстве значительно меньшего числа стран принцип компетенции-компетенции закреплен одновременно в отрицательном аспекте, что означает - государственный суд обязан объявить об отсутствии у него компетенции в случае наличия арбитражного соглашения.

Отрицательный аспект доктрины компетенции-компетенции был признан французской судебной практикой, а затем и закреплен на законодательном уровне путем внесения в 2011 г. поправки в ст. 1148 ГПК Франции, положения которой (в силу отсылки к ст. 1506 ГПК) применяются и к международному коммерческому арбитражу. Арбитражное соглашение даже не должно быть a priori действительным, чтобы исключить компетенцию государственного суда; оно лишь не должно быть явно недействительным или явным образом неприменимым. В данном случае имеет место так называемый отрицательный контроль, т.е. априорная оценка действительности арбитражного соглашения. В соответствии со сложившейся судебной практикой недействительность или неприменимость должны быть совершенно очевидны (французская судебная практика очень требовательна к этим условиям). Тем не менее, положения ст. 1449 ГПК позволяют сторонам обратиться в государственный суд за обеспечительными мерами при условии, что состав арбитража еще не сформирован.

Недавно судебная практика пошла еще дальше. Первая палата по гражданским делам Кассационного Суда в решении от 12 октября 2011 г. исключила компетенцию французских судов по рассмотрению спора о возможности арбитров, постоянно проживающих во Франции, продолжить участие в разбирательстве, поскольку арбитраж, место которого находится за границей, является независимым судебным органом. Как следствие, французский суд не может вмешиваться в процесс.

2. Ограниченный контроль за решениями арбитражей, вынесенными во Франции и за ее пределами. Очевидный факт, свидетельствующий о стремлении французских судов создать благоприятные условия для развития международного коммерческого арбитража, заключается в том, что контроль в отношении арбитражных решений не является жестким. Это касается как случаев контроля за отменой арбитражных решений, вынесенных во Франции, так и случаев признания и приведения в исполнение арбитражного решения, вынесенного во Франции или за ее пределами.

Так, одно из оснований для подачи ходатайства об отмене арбитражного решения, закрепленное в ст. 1520 ГПК Франции, предусматривает, что такое ходатайство может быть заявлено в случае, когда признание и приведение в исполнение арбитражного решения противоречит международному публичному порядку. Однако судебная практика крайне вольно истолковывает данную статью, требуя, чтобы нарушение публичного порядка буквально «бросалось в глаза», и создавая таким образом отдельную категорию арбитражных решений, нарушающих международный публичный порядок, но не «явно, реально и конкретно», которые, соответственно, могут быть признаны и исполнены на территории Франции.

Финансовый кризис, который преодолевают Франция, Европа и мир в целом с лета 2007 г., часто сравнивают по своим масштабам с кризисом 1929 г. Разумеется, использование исторического опыта является вполне корректным. Однако в тот период времени склонность к процессуальному разрешению споров наблюдалась в значительно меньшей степени, чем в наше время. Сегодня процессуальное разбирательство (процессуализация правоотношения) может осуществляться в различных судах: государственных и арбитражных. Появление возможности рассмотрения в национальных судах споров с участием иностранных лиц и развитие различных арбитражных процедур дают субъектам правоотношения, затронутого финансовым кризисом, широкий выбор способов разрешения споров. Как они осуществляют этот выбор? Появляется ли специальный суд, подходящий для рассмотрения споров, связанных с финансовым кризисом, и если да, то по каким причинам?

Для того, чтобы ответить на эти вопросы, крайне важно установить, что именно мы называем «спорами, связанными с кризисом». Если придерживаться широкого подхода, то любой или практически любой спор, имеющий характер экономического, может быть связан с финансовым кризисом. Однако для того, чтобы изучить реальное влияние финансового кризиса на выбор 
способа разрешения споров, следует применять более узкий подход. «Спором, связанным с финансовым кризисом», целесообразно считать спор, вызванный неплатежом должника в связи с крайне неблагоприятной конъюнктурой рынка и осуществление которого может привести (или нет) к банкротству должника.

Финансовый кризис породил новую разновидность споров, инициируемых частными лицами-кредиторами по государственным обязательствам, по которым государство отказывается платить. Раньше ситуация неплатежеспособности государства регулировалась на межгосударственном уровне. В качестве примеров можно привести некоторые знаменитые дела Постоянной палаты третейского суда (в частности, дела по русским, бразильским и норвежским займам). Кроме того, Договор от 27 мая 1997 г., заключенный между Правительством Французской Республики и Правительством Российской Федерации об окончательном урегулировании взаимных финансовых и имущественных требований, возникших до 9 мая 1945 г., также показывает, что сложности, связанные с возмещением российских долгов были урегулированы на межгосударственном уровне. В настоящее время ситуация неплатежеспособности государства является предметом споров в государственных и арбитражных судах.

Другой тип споров, напрямую порожденный кризисом, касается, безусловно, банкротств. Банкротство крупных банков (Lehman Brothers в США или Fortis в Европе), связанное с их чрезмерной вовлеченностью в рынок кредитования, имеет очевидные международные последствия, что подтверждается многочисленными спорами, рассматриваемыми разными государственными европейскими судами, с участием названных банков.

Первый из названных видов споров (спор о государственном долге), одной из сторон которого является государство, позволяет кредиторам обратиться в особый форум: МЦУИС (Международный центр по урегулированию инвестиционных споров) - новый суд по защите «инвесторов» по государственным займам в период кризиса.

Франция, как и 26 других государств-членов ЕС (за исключением Латвии и Польши), является участницей МЦУИС (образованного на основании Вашингтонской конвенции о порядке разрешения инвестиционных споров между государствами и иностранными лицами других государств 1965 г.). Кроме этого, Франция, как и другие государства-члены ЕС, заключила множество двусторонних договоров о защите инвестиций, предусматривающих в качестве механизма разрешения инвестиционных споров обращение в арбитражный суд МЦУИС. Российская Федерация подписала Вашингтонскую конвенцию, но до сих пор не ратифицировала ее.

МЦУИС является «новым» местом разрешения споров для кредиторов по государственным долгам ввиду того, что арбитражное решение МЦУИС, вынесенное по делу Abaclat и др. vs Аргентина 4 августа 2011 г., признало компетенцию МЦУИС по заявлению, поданному от имени 180000 итальянских обладателей аргентинских долговых обязательств (позднее их число было сокращено до 60 000). Необходимо подчеркнуть, что это решение было принято двумя арбитрами, а третий арбитр составил особое мнение, выражающее его полное несогласие с таким решением.

Данное дело порождает множество правовых вопросов. Прежде всего, возникает вопрос, может ли приобретение государственных займов считаться инвестицией (что, в свою очередь, обосновывает компетенцию арбитражного суда МЦУИС). Далее, возникает вопрос о возможности подачи в такой суд столь массового иска, поскольку ни Вашингтонская конвенция, ни Арбитражный регламент МЦУИС не содержат норм, относящихся к массовому или коллективному арбитражу (class arbitration). Также возникает вопрос, мог ли арбитражный суд игнорировать оговорку о подсудности, включенную в ряд рассматриваемых государственных долговых обязательств и предусматривающую в разных случаях подсудность нью-йоркским, швейцарским или итальянским судам. Наконец, четвертый вопрос, в большей степени социологический, нежели юридический: что могло послужить мотивом для передачи дела кредиторами государственного долга арбитражному суду МЦУИС вместо установленных в соглашениях государственных судов?

Арбитражное решение по делу Abaclat и др. vs Аргентина имело последствия в виде двух других дел против Аргентины, появившихся 
по инициативе держателей государственных облигаций (Giovanni Alemanni u дp.vs Aргентина № ARB/07/8 и Ambiente Ufficio S.p.A. vs Аргентина №ARB/08/9). Арбитражное решение, предусматривающее компетенцию арбитражного суда МЦУИС, было вынесено по делу Ambiente Ufficio S.p.A. vs Аргентина 8 февраля 2013 г. Сегодня эта проблема напрямую затрагивает государство-член ЕС, так как Греция является ответчицей в арбитражном суде МЦУИС по заявлению, поданному словацким банком в отношении реструктуризации греческого долга (Poštová banka, a.s. et ISTROKAPITAL SE vs Греииu №ARB/13/8).

Если бы Франция отказалась платить по своим долгам, кредиторами по которым на 61,9\% являются нерезиденты, ей мог бы быть предъявлен иск в арбитражный суд МЦУИС (естественно, при условии, что держатели долговых документов являлись бы гражданами государства, с которым Франция заключила договор о защите инвестиций). Россия в связи с отсутствием ратификации Вашингтонской конвенции от этого защищена.

Однако обращение к инвестиционному арбитражу не является единственным методом разрешения споров, избранным кредиторами государств. Кроме того, существуют серьезные сложности при исполнении решения, обязывающего государство выплатить долг кредиторам.

Выпуск государственных долговых обязательств часто производится в рамках типового договора эмиссии, заключаемого финансовыми посредниками. Эти договоры могут содержать оговорку о подсудности, посредством которой государство отказывается от своего юрисдикционного иммунитета. Такая ситуация возникла в деле об аргентинском долге, которое рассматривалось в США и имело последствия во множестве европейских и неевропейских государств. В 2006 г. Нью-йоркский суд (компетентный рассматривать данное дело на основании оговорки о подсудности), обязал Аргентину выплатить частному инвестиционному фонду (NML) сумму, представляющую номинальную стоимость долговых документов, приобретенных фондом (несмотря на то, что покупка этих документов была осуществлена после объявления Аргентины неплатежеспособной). В связи с отказом Аргентины произвести выплату долга, частный инвестиционный фонд пытается наложить арест на имущество, принадлежащее аргентинскому правительству и находящееся на территории Соединенного Королевства, Швейцарии, Бельгии и Франции, используя решение американского суда. Кассационный суд Франции (как и бельгийские суды) в трех решениях от 28 марта 2013 г. посчитал, что Аргентина не отказалась от своего иммунитета от принудительного исполнения и подтвердил решения, постановляющие снятие ареста с имущества по искам, поданным NML.

Л.А. Прокудина в своих докладах по теме «Альтернативные способы разрешения коммерческих споров» обратила внимание на влияние экономического кризиса на открытость России альтернативным способам разрешения коммерческих споров.

Основными нормативными актами, регулирующими судебную систему Российской Федерации, являются Конституция РФ и Федеральный конституционный закон «О судебной системе Российской Федерации» от 31 декабря 1996г. В соответствии с ними в России в настоящее время действует судебная система, включающая три ветви судебной власти. Ими являются: Конституционный Суд РФ; система арбитражных (хозяйственных) судов; система судов общей юрисдикции (доклад был представлен до принятия законов о слиянии ВАС РФ и ВС

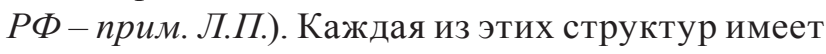
в соответствии с законом вполне определенную компетенцию. В самых общих чертах ее разграничение следующее:

судебный конституционный контроль за соответствием федеральных законов и иных нормативных актов Конституции РФ осуществляет Конституционный Суд РФ;

разрешение экономических споров и иных дел, отнесенных к их компетенции, - функция арбитражных судов;

разрешение уголовных, гражданских, административных и иных дел - компетенция общих судов.

Все эти суды, за исключением мировых судей судов общей юрисдикции, отнесены законом к разряду федеральных судов. По всей территории России эти суды единообразны: законодательство, регламентирующее их создание, формирование корпуса судей, функционирование относится к федеральной компетенции. 
Кроме государственных судов, в России созданы и действуют третейские суды. Они, являясь аналогами зарубежных арбитражей, не входят в судебную систему России. Третейские суды могут быть постоянно действующими или создаваться для рассмотрения одного дела (ad hoc). В России в настоящее время существует более 330 постоянно действующих третейских судов для рассмотрения коммерческих споров (в 50 регионах); аналогичные третейские суды для рассмотрения иных дел граждан пока практически не действуют в связи с отсутствием инициативы граждан.

Третейские суды вправе рассматривать гражданские дела, если закон не вводит специальных изъятий для использования третейской процедуры. Например, дела, вытекающие из публично-правовых отношений, о банкротстве не могут рассматриваться третейскими судами. Для возможности правомерного рассмотрения дела третейским судом должны быть соблюдены следующие условия:

1. в законе не должно содержаться запрета для рассмотрения данного дела третейским судом;

2. между сторонами заключена предварительная письменная договоренность о рассмотрении данного дела (спора) конкретным третейским судом. В противном случае решение третейского суда может быть отменено, если сторона обратиться в арбитражный суд с заявлением об отмене такого решения и докажет, что решение третейского суда вынесено по спору, не предусмотренному третейским соглашением или не подпадающему под его условия, либо содержит постановления по вопросам, выходящим за пределы третейского соглашения (ст. 233 АПК РФ);

3. стороны не возражают против третейского разбирательства.

Законность принятого российским третейским судом решения может быть проверена государственным судом (например, арбитражным судом по коммерческому спору), если стороны предварительно не договорились об обязательности и неоспоримости принимаемого третейским судом решения. При этом арбитражный суд не является вышестоящим по отношению к третейскому суду и не представляет собой обычную проверочную (апелляционную, кассационную) инстанцию для его решений. Европейская конвенция о внешнеторговом арбитраже 1961 г. (ст. IX) предусматривает возможность отмены международного арбитражного решения, но только в государстве участнике Конвенции, в котором или по закону которого это решение было вынесено. Решение иностранного арбитража также может быть оспорено в российском арбитражном суде, если при его принятии были применены нормы законодательства Российской Федерации.

Обращений в арбитражный суд с заявлениями об оспаривании решений третейских судов совсем немного (в 2012 году их было всего 351), и их проверка предусмотрена по весьма ограниченному кругу вопросов, представляющих основания для отмены решения третейского суда. В частности, арбитражным судом проверяется:

1) арбитрабельность спора, т.е. наличие права третейского суда на рассмотрение данного дела;

2) наличие несоответствия соглашению сторон о составе суда или процедуре третейского разбирательства, нарушений основных положений третейской процедуры, в частности, надлежащего уведомления стороны об избрании (назначении) третейских судей или о третейском разбирательстве, в том числе, о времени и месте заседания третейского суда, отсутствие уважительных причин у стороны, не представившей свои объяснения третейскому суду;

3) отсутствие при вынесении решения нарушений основополагающих принципов российского права.

Таким образом, полномочия арбитражного суда ограничены проверкой решения третейского суда лишь с точки зрения его законности. Ставить под сомнение обоснованность решения законом арбитражному суду прямо запрещено (ст. 46 Федерального закона от 24.07.2002 № 102-Ф3 «О третейских судах в Российской Федерации»). Решение третейского суда подлежит исполнению стороной добровольно или принудительно - государственной службой судебных приставов-исполнителей. Для этого заинтересованное лицо должно обратиться в государственный (по коммерческим делам - в арбитражный) суд за выдачей исполнительного листа. При этом арбитражный суд также проверяет правильность принятого третейским 
судом решения по тем же основаниям, что и при его оспаривании. Подобных дел в 2012 году было 4010.

В последнее время в выступлениях представителей бизнеса и руководства страны отмечается, что бизнес-сообщество снизило доверие к системе арбитражных судов и по возможности старается вывести рассмотрение споров за пределы российской юрисдикции. Преодоление существующей проблемы является одной из задач, на решение которых направлена Федеральная целевая программа «Развитие судебной системы России на 2013-2020 годы». Одним из способов исправления столь нежелательной ситуации является дальнейшее развитие системы третейских судов с реализацией ее процедурных преимуществ.

В настоящее время идет процесс активизации использования иных примирительных процедур, в частности, медиации. Для этого 27.07.2010 г. был принят Федеральный закон «Об альтернативной процедуре урегулирования споров с участием посредника (процедуре медиации)» (далее-Закон о медиации) и внесены изменения в процессуальное законодательство. Ведется серьезная работа, направленная на разъяснение преимуществ примирительных процедур и адресованная, в первую очередь, представителям бизнес-сообщества. По всей России открываются центры для подготовки кадров медиаторов. Изменения процессуального законодательства в этом направлении связаны с предоставлением суду дополнительного времени на прерывание судебной процедуры (отложение подготовительных действий или судебного разбирательства до 60 дней) для реализации намерений сторон использовать примирительную процедуру.

В АПК РФ также предусмотрена реализация положительных результатов медиации по находящимся в производстве арбитражного суда делам в виде заключения мирового соглашения (ст. 139-142), признания и отказа от иска (ст. 49), признания или заключения соглашения о признании фактических обстоятельств дела (ст. 70).

В настоящее время ВАС РФ подготовил проект федерального закона, направленного на совершенствование примирительных процедур, в котором предусматривается закрепление института судебного посредничества, создаются условия для активизации роли суда по содействию сторонам в урегулировании споров, в том числе, возникающих из административных и иных публичных правоотношений. Это будет способствовать нахождению сторонами взаимоприемлемого способа урегулирования спора либо (при его недостижении) сближению позиций сторон, в том числе, и по спорам, где одной из сторон является государственный орган. Предлагается предоставить арбитражному суду возможность откладывать судебное разбирательство по своей инициативе, если он сочтет возможным примирение сторон.

К осуществлению функций судебных посредников предлагается привлекать помощников судей, иных сотрудников аппарата суда, имеющих юридическое образование, и судей в отставке, список которых будет утверждаться Пленумом ВАС РФ, а также по предложению сторон назначать их из списков посредников, представленных в арбитражный суд организациями, обеспечивающими проведение примирительных процедур. В качестве материального стимулирования этих процедур предлагается возвращать до 70\% государственной пошлины истцу при урегулировании спора по результатам таких процедур.

Современная российская судебная система, как и большинство судебных систем в мире, работает в условиях постоянно возрастающих перегрузок. Количество поступающих на рассмотрение в государственные арбитражные суды заявлений постоянно растет. Со вступлением мировой экономики в кризисный период эта тенденция усиливается, продолжает постепенно увеличиваться и количество исковых заявлений, поданных иностранными компаниями. Так, в 2011 году оно достигло 0,3\% от общего числа, при этом 58\% «иностранных» исков было удовлетворено.

Это приводит к значительному усилению ежедневной нагрузки судей, что неминуемо влияет на сроки рассмотрения дел и качество выносимых ими решений. За 2012 год в среднем по России государственный арбитражный судья рассматривал 57 дел в месяц, а в некоторых судах нагрузка составляла 120 дел в месяц. Руководство системы государственных арбитражных судов понимает, что в подобном режиме нельзя рассматривать дела, в таком режиме можно только штамповать заранее заготовленные решения. Проблема снижения трудозатрат судей по рассмотрению и разрешению 
гражданских дел является сверхактуальной, и не только применительно ко всей судебной системе России в целом, но и применительно к деятельности отдельно взятых судов.

В России сложилась практически катастрофическая ситуация, и с начала XXI века активно изыскиваются средства для ее преодоления. Одним из приоритетных направлений совершенствования существующих в России механизмов разрешения споров и защиты нарушенных субъективных прав признано использование различных примирительных процедур. В целях реализации данного направления и был принят Закон о медиации.

В соответствии с Законом деятельность медиатора может осуществляться как на профессиональной, так и на непрофессиональной основе. В первом случае эту работу вправе выполнять лица, достигшие 18 лет, обладающие полной дееспособностью и не имеющие судимости. Осуществлять деятельность медиатора на профессиональной основе могут лишь лица, достигшие 25 лет, имеющие высшее образование и получившие дополнительное профессиональное образование по вопросам применения процедуры медиации (ст. 15, 16 Закона о медиации).

В качестве медиатора может выступать только физическое лицо, к которым в первую очередь относится гражданин РФ. Закон ничего не говорит о существовании возможности выполнять функции медиатора иностранным гражданином и лицом без гражданства. Однако его комментаторы признают, что эти физические лица могут быть медиаторами при условии их законного нахождения на территории РФ и соответствия предъявляемым Законом требованиям к кандидатуре медиатора.

В России ведется работа, направленная на разъяснение преимуществ использования примирительных процедур, а также открываются центры по подготовке соответствующих кадров. Процесс этот проходит очень медленно. Так, в настоящее время в стране сформировано около 47 центров по подготовке медиаторов, которые расположены только в 24 регионах. С появлением подготовленных кадров медиаторов только начинается их работа. Вместе с тем важно отметить, что в 2011 году примирительные процедуры с участием медиаторов использовались в государ- ственных арбитражных судах в рамках рассмотрения всего 11 дел.

В целях более интенсивного развития примирительных процедур в России разрабатывается целый ряд дополнительных мер, в том числе законодательного характера. В частности, сформулировано предложение об увеличении размера государственной пошлины по государственным арбитражным делам, что может заставить заявителя задуматься об оптимальном выборе способа защиты права прежде, чем обращаться в государственный арбитражный суд.

Выдвинуто предложение ввести обязательный досудебный порядок урегулирования споров по определенным категориям дел на стадии их подготовки к судебному рассмотрению. При этом подобная обязанность включает лишь принудительную явку сторон к медиатору, который должен помочь им достичь соглашения по спору. Никакого использования принуждения к заключению соглашения не допустимо. В настоящее время предлагается провести соответствующий эксперимент в ряде регионов России, где уже существуют центры медиации и сформировался контингент медиаторов. Предполагается, что опыт обязательного примирения станет толчком для развития добровольной медиации.

Еще одно предложение уже оформлено в законопроект ВАС РФ, предусматривающий закрепление института судебного посредничества, которое представляет собой самостоятельную, отличную от медиации, примирительную процедуру. Введение этого института создает условия для активизации роли суда по содействию сторонам в урегулировании споров, в том числе возникающих из административных и иных публичных правоотношений. Это будет способствовать нахождению самими сторонами взаимоприемлемого способа урегулирования спора либо (при его не достижении) сближению их позиций, в том числе, и по спорам с государственными органами. Государственному арбитражному суду предоставляется право откладывать судебное разбирательство по своей инициативе, если он сочтет возможным примирение сторон.

К осуществлению функций судебных посредников предлагается привлекать не медиаторов, а работников аппарата арбитражного суда (помощников судей, не принимающих участие в рассмо- 
трении конкретного дела, иных сотрудников аппарата суда, имеющих юридическое образование, и получивших соответствующую подготовку) и судей в отставке, список которых будет утверждаться Пленумом ВАС РФ. Если в процессе примирительной процедуры, срок которой не может превышать 2 месяца, стороны не достигнут взаимоприемлемого результата примирения, судебное разбирательство возобновляется. В качестве материального стимулирования этих процедур предлагается возвращать до 70\% уплаченной государственной пошлины истцу при урегулировании спора по результатам таких процедур.

Еще одним способом, способствующим развитию примирительных процедур, можно признать проведенный в ряде государственных судов Свердловской области на базе Центра медиации Уральской государственной юридической академии правовой эксперимент «Разработка и апробация механизмов интеграции медиации в гражданское судопроизводство». Основной целью эксперимента явились поиск оптимальной модели согласования примирительной процедуры (медиации) с гражданским судопроизводством, и разработка форм взаимодействия между судом и медиаторами. Правовой эксперимент проводился с 1 апреля 2011г. по 31 декабря 2012 г. и реализовывался по трем направлениям:

1) обучение судей основам медиации и разработка методики разъяснения судьями участникам гражданского процесса права на урегулирование спора в рамках процедуры медиации;

2) углубленное обучение группы судей медиативным техникам;

3) проведение медиации по гражданским делам, разработка форм и механизмов взаимодействия медиатора и суда.

Центром медиации были предложены рекомендации по определению споров, которые являются потенциально «медиабельными» и «немедиабельными», проработана в тренинговом формате технология разъяснения.

Обучение прошли 74 судьи. По итогам обучения, имея более полное представление о медиации, судьи смогли не просто разъяснять сторонам их право обратиться к медиатору, а объяснять сущность и преимущества медиации, возможности и ограничения данной процедуры. После таких бесед с судьями стороны стали проявлять заинтересованность к примирительным процедурам, рекомендации судей вызывали большее доверие к медиации со стороны участников судопроизводства. В результате число обращений участников гражданского процесса к медиации стало расти.

В здании судов организовывались информационные встречи с медиатором. В результате применения медиативных техник судьями, прошедшими обучение, соотношение прекращенных и рассмотренных дел у этих судей увеличилось и превысило средние показатели по суду на 200,5\%.

Сегодня проблема конкуренции юрисдикций актуальна для национальных судов в большинстве стран мира. Многое зависит от политики, которой придерживаются судебные системы: от позиции разумной сдержанности до возможности экспансии. Выбор юрисдикции может быть обусловлен автономией воли сторон, их независимым частным соглашением. Частные лица при заключении договора учитывают преимущества и недостатки различных национальных правовых систем исходя из оценки эффективности юрисдикции, степени предсказуемости решений, продолжительности процедур и размера судебных издержек. В частности, как отмечает председатель Федерального Верховного Суда ФРГ Клаус Тольксдорф, германские граждане все чаще обращаются в американские суды, где можно взыскать убытки, не предусмотренные в Германии, хотя именно при обращении к иностранной юрисдикции сторона может столкнуться с непредвиденными рисками. Специалисты большинства стран соглашаются, что при безусловной необходимости государственного регулирования вопросов признания и исполнения решений, вынесенных иностранными судами, в соглашения сторон и автономию их воли государство вмешиваться не должно.

Процессуальное законодательство России позволяет государственным арбитражным судам рассматривать дела с участием иностранных компаний, однако достаточно часто сам российский государственный арбитраж приходит к выводу, что наш суд - это forum non conveniens, «неудобное место» для рассмотрения международных коммерческих споров.

При этом хотелось бы отметить, что в современной российской правоприменительной прак- 
тике появились случаи признания иностранных судебных решений в отсутствие международного договора, на основании принципов взаимности и международной вежливости. Например, дело об исполнении на территории РФ решения английского суда по делу компании «БоэглиГравюр С.А.» о возмещении судебных издержек за рассмотрение патентного спора с российской компанией «Дарсайл-АСП». Несмотря на то, что между РФ и Великобританией отсутствует договор о взаимном признании и исполнении судебных решений, ходатайство «Боэгли-Гравюр» о признании и приведении в исполнение решения английского суда было удовлетворено Арбитражным судом г. Москвы (Определение от 12 февраля 2012 г. по делу № А40-119397/11-63-950) и оставлено в силе кассационной инстанцией. В России с должника (российской компании) были взысканы судебные издержки за рассмотрение спора в английском суде в сумме около $£ 20$ млн.

Суд пришел к выводу, что даже в отсутствие международного договора между РФ и государством, о признании и исполнении решения суда которого заявляется в российском суде, такое иностранное решение подлежит исполнению на основании принципов взаимности и международной вежливости. Английское право допускает возможность приведения в исполнение решений российских судов английскими судами, что было подтверждено в судебном заседании экспертным заключением профессора МЧП в Оксфордском университете Эдриана Бриггса. В связи с тем, что решения российских судов признаются и приводятся в исполнения судами Соединенного Королевства, Арбитражный суд г. Москвы пришел к выводу, что решение английского суда подлежит признанию и исполнению на территории РФ на основании принципов взаимности и международной вежливости.

Необходимо отметить, что оптимальной мерой преодоления многих существующих проблем является выработка комплексного подхода для снижения уровня конфликтности в обществе, главной составляющей которого может стать дальнейшее развитие системы ADR.

В ходе представления докладов и их обсуждения участники проекта согласились с тем, что при всех различиях общие подходы к методологии международного частного права, проблемам федерализма, защите несовершеннолетних, статусу иностранных корпораций, разрешению международных коммерческих споров во многом для Франции и России являются совпадающими. В целях минимизации негативных последствий глобального финансового и экономического кризиса эти подходы следует максимально унифицировать. Дальнейшее развитие совместного научного сотрудничества может способствовать достижению этой цели.

\section{Библиография:}

1. Составитель обзора: И.В. Гетьман-Павлова, доцент кафедры международного частного права Национального исследовательского университета «Высшая школа экономики», кандидат юридических наук, 119017, г. Москва, ул. Малая Ордынка, д. 17 8-916-524-48-74; getmanpav@mail.ru

\section{References (transliteration):}

1. Sostavitel' obzora: I.V. Get'man-Pavlova, dotsent kafedry mezhdunarodnogo chastnogo prava Natsional'nogo issledovatel'skogo universiteta «Vysshaya shkola ekonomiki», kandidat yuridicheskikh nauk, 119017, g. Moskva, ul. Malaya Ordynka, d. 17 8-916-524-48-74; getmanpav@mail.ru 